\title{
Interventions to improve spontaneous adverse drug reaction reporting by healthcare professionals and patients: systematic review and meta-analysis
}

\section{Abstract}

\section{Introduction}

The aim of this study was to evaluate the effectiveness of interventions used for improving ADR reporting by patients and healthcare professionals.

\section{Areas covered}

A systematic review of literature was conducted by searching Medline, Embase and Cochrane Central Register of Controlled of Trials. Meta-analysis of randomised controlled trials ( $R C T s ; n=5$ ) was conducted to estimate the pooled risk ratio for the effectiveness of interventions on ADR reporting rates. Data from observational studies were synthesised using narrative synthesis approach.

\section{Expert Opinion}

A total of 28 studies were included. All except one study targeted healthcare professionals using educational, technological, policy, financial and/or mixed interventions. The results showed that financial and face-to-face educational interventions improved quality and quantity of ADR reporting when compared with interventions not involving face-to-face interactions. However, the quality of studies was generally low. Meta-analysis showed a statistically significant 3.5-fold overall increase in reporting of ADRs [RR 3.53; $95 \%$ CI $(1.77,7.06)]$ in the intervention group compared to the control. There was a lack of consideration of theory and sustainability in the design of the interventions. There is a need to develop and test theory-based interventions and target patient reporting. More research needs to be conducted in the low-and-middle-income countries.

\section{Study protocol:}

Protocol registration ID PROSPERO CRD42019162209 Available from: https://www.crd.york.ac.uk/prospero/display record.php?ID=CRD42019162209

\section{Articles highlights}

- It is known that up to $94 \%$ of adverse drug reactions (ADR) are not reported. Under-reporting delays drug safety signals compromising patient safety.

- There is lack of high-quality interventions that aim to increase ADR reporting.

- Limited evidence suggests face-to-face education interventions combined with financial incentives tend to increase ADR reporting by healthcare professionals. 
- This systematic review identifies lack of interventions targeted at patients to improve ADR reporting.

- More research studies are needed in low-and-middle-income countries.

Keywords: Adverse Drug Reactions, Drug utilisation, Medication Safety, Pharmacovigilance

\section{Reporting Guidelines}

This systematic review and meta-analysis conform to the PRISMA reporting guideline. A PRISMA checklist has been provided as an electronic supplementary material. 


\subsection{INTRODUCTION}

When a drug is introduced to the market, its safety profile is poorly understood, and the spontaneous reporting of adverse reactions remains an essential element for the dissemination of safety signals. An adverse drug reaction (ADR), as defined by the World Health Organisation is 'a response to a drug which is noxious and unintended, and which occurs at doses normally used in humans for the prophylaxis, diagnosis, or therapy of disease, or for the modifications of physiological function' [1]. ADRs are responsible for unplanned hospital admissions and mortality, with elderly and children most likely to suffer ADRs. It is estimated that approximately 1 in 10 admissions of older persons are due to ADRs [2]. There are also economic consequences to the healthcare system. It was reported that ADRs costs the European Union member states and the US approximately $€ 79$ billion [3] and $\$ 30$ billion [4] annually respectively.

One of the main limitations of the spontaneous reporting system of ADRs is underreporting. A recent systematic review of 37 studies across 12 countries showed that the median under-reporting rate was $94 \%$ [5]. Under-reporting delays drug safety signals compromising abilities of national pharmacovigilance centres to generate drug safety signals. Numerous factors contribute to underreporting of ADRs, which include: lack of awareness for the purpose of ADR monitoring and reporting, lack of knowledge on how to use spontaneous reporting of ADRs, restricted access to reporting tools, uncertainty in ADRs associated with many drugs, time constrictions on healthcare professionals and patients, bias due to intensive media coverage of some ADRs, and failure to verify diagnostics reported increases data restriction $[6,7]$.

Pharmacovigilance is an umbrella term encapsulating the systematic detection, reporting, assessment, understanding and prevention of ADRs [8]. Effective and efficient pharmacovigilance systems provide surveillance of marketed medicines, thus are essential to protect the health of the public and limit healthcare costs caused by ADR-related complications. Globally, post-marketing surveillance of medicines is mainly coordinated by national pharmacovigilance centres responsible for collecting and analysing reports of ADRs, making decisions based on the analysis of the reports and alerting prescribers, manufacturers and the public to new risks of ADRs.

The aim of this study was to evaluate the effectiveness of interventions to improve the quantity and quality of spontaneous reporting of ADRs amongst both patients and healthcare professionals. This study will update the evidence presented in a previous systematic review on the topic area [9] which considered published literature until 2010. In addition, the previous review did not consider meta-analysis in their approach to 
evidence synthesis. Given evolving international pharmacovigilance regulations, practices and increased emphasis on patient reporting of ADRs, there is a need to update the review to provide researchers, practitioners and stakeholders with up-to-date evidence on the nature and effectiveness of pharmacovigilance interventions.

The primary outcome of the study was the quantity of ADRs reported as a result of the intervention including improvement in the number or rate of reporting. Secondary outcome included the quality of ADR reporting including the nature of ADRs reported (e.g. serious, non-serious ADRs) and completeness of the reports.

\subsection{BODY}

\subsection{Methods}

This study adhered to Cochrane guidelines [10] and Preferred Reporting Items for Systematic Review and Meta-Analysis reporting guidelines (PRISMA) [11] to conduct and report the review respectively. A protocol was prepared using Preferred Reporting Items for Systematic Review and Meta-Analysis Protocols (PRISMA-P, CRD42019162209) [12]. An electronic search of MEDLINE, EMBASE, and Cochrane trials register databases were undertaken using Medical Subject Headings (MeSH) and natural language key words, Boolean operators, truncations $(*)$ and wild cards $(\$)$. A search strategy using keywords and Medical Subject Headings was utilised to perform a search (online resourcesupplementary material 1 ). The reference lists of included studies were hand searched to identify any additional references for inclusion. In particular we considered all references within a previous systematic review [9] conducted on the same topic.

\subsection{Eligibility criteria}

No restrictions to country of origin, publication language was applied. All forms of interventional designs were considered. Literature from year 2000 till August 2019 that sought to improve either a) quality or b) quantity or both of spontaneous ADR reporting were included. Educational research with student participants, interventions not including qualified healthcare practitioners or patients were excluded as well as the interventions related to devices and planned ADR surveillance monitoring programmes, such as those used for mass vaccinations. Abstract only publications including conference abstracts were excluded.

\subsection{Screening and selection}


Screening was conducted by one pair of researchers (VP, DS; VP, AH) acting independently in three consecutive stages: screening of titles; screening of abstracts; screening of full text against the eligibility criteria.

\subsection{Data extraction and quality assessment}

A data extraction form was developed based on the review aim, refined, reviewed and piloted. Cochrane risk of bias tool for Randomised Controlled Trials [13] and The Critical Appraisal Skills Programme (CASP) quality assessment tool for cohort study (for all other study designs) was used to assess study quality [14].

\subsection{Data Synthesis}

The technique for data synthesis varied across different study designs. Data from RCTs $(n=5)$ were combined using random effects meta-analysis. We reported pooled risk ratio ( $95 \%$ CI) to demonstrate the effectiveness of interventions to improve the quantity, i.e. rate of ADR reporting. Relative risk data adjusted for duration of follow-up was extracted and used in meta-analysis, if reported in individual studies. In instances, where the effectiveness of intervention was tested at multiple time-points and time-adjusted relative risk was not reported, the relative risk for last follow-up time point was extracted. Forest plots were produced using RevMan $®$. Forest plots refer to graphical representation of individual studies in a meta-analysis and allow researchers to graphically identify whether the cumulative evidence in relation to effectiveness of interventions under study favours control or experimental group [15]. In relation to the impact on the quality of ADR reporting, it was not possible conduct a meta-analysis due to heterogeneity in the definition and lack of clarity around seriousness of ADRs and completeness of ADRs.

We did not undertake meta-analysis for non-randomised controlled studies, due to the presence of confounding factors that could affect overall findings and introduce bias [16]. Therefore, a narrative synthesis of the outcomes was undertaken using summary tables extracting data on the rate and quality of ADR reporting.

\subsection{Results}

A total of 6812 unique titles were screened, of which 28 studies [17-44] fulfilled eligibility criteria for inclusion in the review (online resource- supplementary material 2 ). Most studies originated from Portugal $n=5)$, followed by Sweden $(n=4)$ and Spain $(n=4)$ (table 1 ). Only seven of the studies used a randomised controlled design of which five studies used cluster randomisation design. The rest were either quasi experimental, observational pre-post or time series analysis (table 1 ). All studies focused on healthcare professionals apart from one study in the UK which also focused on general members of the public. The 
study focused on patients [22] aimed to assess patterns in reporting of ADRs via the Yellow Card Scheme following a Scottish community pharmacy patient Yellow Card promotional campaign (table 1). A mix of healthcare professionals in various settings was targeted by other studies including physicians, nurses and pharmacists. Four studies exclusively targeted pharmacists (table 1 ).

\subsection{Risk of bias within RCTs}

High risk of bias was identified for most of the domains for the included studies (figure 1 , online resource- supplementary material 3). In particular, allocation concealment (selection bias), blinding of participants and personnel (performance bias) was not discussed sufficiently in any of the seven trials to allow a judgement $[25,27,30,31,34$, $38,40]$. Therefore, there was insufficient information to permit judgment of high or low risk. Selection bias in relation to random sequence generation was high in two studies $[30,34]$ as allocation was by the availability of the intervention and this information was unclear in another study [25]. Contamination between the intervention and control groups could not be ruled out in all of the seven RCTs.

Overall, the quality of the non-randomised studies was also considered to be low. Fourteen studies did not include a control group in their study design and where a control group was used, it was often not clear whether the nature of likely ADRs to be reported were identical across both groups in relation to clinical settings and patient demography (online resource- supplemental material 4). There was a general lack of consideration about what factors other than the interventions i.e. confounding factors during the study may have impacted on the observed changes. Development and validation of data collection tools were poorly described. Follow up lacked adequate lag time in studies particularly those adopting educational interventions as evaluation often measured transient impact on knowledge and practice. Sample size of participants or the report numbers were often low compromising the generalisability of the findings.

A lack of standardised definition and classifications of ADRs were observed in the included studies. Classification systems were based on seriousness (serious and non-serious), whether expected and unexpected, and whether labelled and unlabelled (table 1).

Table 1 to appear here

\subsection{Nature of interventions}

Educational interventions 
Twenty-one studies implemented educational interventions (table 1 and 2). These included passive interventions such as provision of printed training manual about importance of ADR reporting; or the provision of active interventions including telephone interviews, educational workshops, lectures, email reminders, continuing medical education sessions, bulletins, visits to clinics, improving accessibility of the ADR reporting, group sessions and presentations (table 1 and 2).

\subsubsection{Technological interventions}

Three studies utilised electronic systems or features to increase accessibility of ADR reporting system or to prompt reminders about when to use the system for ADR reporting (table 1 and 2).

\subsubsection{Financial interventions}

Financial provisions used in the interventions included the use of lottery tickets, direct monetary rewards, and additional days off work (table 2 ).

\subsubsection{Policy interventions}

Two studies related to evaluation of the impact of new policies aimed at establishing responsibilities and methods for reporting ADRs (table 1 and 2 ).

\subsubsection{Mixed interventions}

Mixed nature of interventions were utilised in five studies including a mix of educational, financial, electronic system or policy interventions. A study [19] evaluated novel organisational policy for reporting adverse drug reactions by streamlining the process of reporting and incorporating ADR reporting mechanisms as part of the organisational accreditation documents. Two studies $[20,21]$ focused on the improved regulation for reporting ADRs resulting from antibiotics use. ADR reporting activity of health professionals was included in performance evaluation of the heads of hospital and department in one study [20] (table 1).

\subsection{Use of theory}

Only three studies used behavioural theory in the development of the intervention $[25,38,40]$. These studies used complacency; insecurity; diffidence; indifference; and ignorance to define key behavioural barriers and facilitators to reporting ADRs. The use of theory was deemed to have allowed the intervention to be designed to address these knowledge and attitude gaps (table 1 ).

\subsection{Intervention outcomes}


Almost all interventions apart from those utilising passive educational approaches showed improvement in the rate of reporting of spontaneous ADRs. However, the unit of measurement and extent of improvement varied across the studies (table 2 ).

\subsubsection{RCTs}

All of the seven RCTs $[25,27,30,31,34,38,40]$ included in the review used educational interventions. A study conducted in Portugal included a one hour educational visit by a pharmacist to hospital and community pharmacists as a group session to address the unmet educational need [38]. The study showed that over the 16 months period, adjusted increase in the total ADR reporting rate attributable to the intervention to be 275.63 per 1000 pharmacist-years which accounted to a 5.87 fold ( $95 \%$ CI $1.98-17.39, p=0.001$ ) increase in reporting rate over 4 months post intervention. Improvement in the serious (10 fold), unexpected ( 4 fold), high-casualty ( 9 fold) and new drug-related ADRs ( 9 fold) were also observed. A sub-group analysis showed that the intervention had no effect on hospital pharmacists and any positive changes were seen only with community pharmacists [38]. Another study in Portugal by the same research group using similar cluster RCT design focused on the physicians using either telephone or workshop interventions [27]. Comparison with the control group showed that the workshop intervention increased the spontaneous ADR reporting rate by an average of 4 -fold (relative risk [RR] 3.97; 95\% CI 3.86, 4.08; p < 0.001) across the 20 months post intervention. Telephone interviews, in contrast was shown to prove less efficient since they led to no significant difference $(p=0.052)$ in the reporting rate and the intervention effect did not last long [27]. Another cluster RCT conducted in Portugal used either telephone interviews (4-12 minutes) or 1 hour workshop workshops to promote ADR reporting amongst hospital and community pharmacists [31]. Outcomes evaluated four months post-intervention showed improvement in ADR reporting rates and quality, although the effects declined over time (table 2).

A cluster RCT conducted in Spain [25] which used an active component (group session 2025 minutes) and a passive component (educational material) to the physicians delivered by pharmacists. The intervention showed educational intervention increased ADR reporting by $65.4 \%$ (95 \% CI 8.2-153.4) over the four month period post intervention. Moreover, the educational intervention had a positive effect on the relevance of reporting, measured as the increase in unexpected reports $(2.06,95 \%$ CI 1.19-3.55) (table 2).

An RCT conducted in Sweden focused on the heads of primary healthcare units which consisted of email communications about the importance of reporting ADR showed no statistically significant effect on the quality or the quantity of ADR reports [34]. Another 
study in Sweden which used a one-page information letters on three occasions to physicians and nurses in primary healthcare unit did not show a significant increase in the ADR reporting rate (mean number of reports per unit \pm standard deviation: $1.0 \pm 2.5$ vs. $0.7 \pm 1.2, \mathrm{P}=0.34$ ), although increase in the number of high quality reports was noticed (table 2) [30].

Five RCTs were included in meta-analysis $[25,27,31,38,40]$. Two RCTs $[30,34]$ were excluded from meta-analysis because of following two reasons: Firstly, mode of delivery of educational interventions in these trials was passive and lacked face-to-face contact component. Combining interventions with different mode of delivery would have introduced clinical heterogeneity and is not recommended. Secondly, data were not reported in an appropriate format to allow meaningful statistical combination.

The meta-analysis found a statistically significant 3.5-fold overall increase in reporting of ADRs [RR 3.53; 95\% CI $(1.77,7.06)]$ in the intervention group compared to the control (figure 2). Furthermore, approximately a 4-fold increase was noted in reporting of serious ADRs [RR 4.18; 95\% CI $(1.69,10.33)]$ and unexpected ADRs [RR 5.16; 95\% CI $(2.42$, $11.03)]$ in the intervention group compared to the control (figure 2).

\subsubsection{Other study designs}

A study in China demonstrated that financial interventions which constituted rewards and penalty led to $855 \%$ increase in the number of ADR reported [20]. When combined with additional regulation, the changes were augmented to over 2,000 fold increase. A $379 \%$ increase in the number of ADR reports were reported by a study on the financial incentives delivered to patients, pharmacists, physicians and nurses in Saudi Arabia [17] The intervention which consisted of employee of the month award for the most frequent reporter, letters of appreciation, extra annual leave and performance also led to increase in the number of serious ADR reporting. One study which used lottery tickets as an economic inducement showed 59\% increase in the ADR reporting rate in the intervention group $(p<0.10)$ [39] (table 2).

The two studies utilising electronic reminders showed positive changes in ADR reporting rates and quality. One study [28] investigated electronic reminders to the electronic patient records or to the desktop computers. The hyperlink took participants to an online ADR reporting form. When comparing with the control group, a statistically significant improvement in reporting was noted. However, outcome follow up only lasted until 4 months post-intervention. Another study [35] used an electronic system to facilitate ADR reporting through easy use, automatic input of certain information, and increased accessibility. A positive improvement in the reporting rate by both the physician and 
pharmacist study participants in the eight months post intervention period were observed (table 2).

Changes in ADR reporting policy alone was shown to only minimally improve ADR reporting practices [19] despite the follow up evaluation was conducted only three months after the introduction of the new policy. Both studies focused on policy/regulatory interventions were specific to a particular clinical setting, Canadian Forces Health Services Group [19] and specific hospitals [21] in China. While one study [19] made a reference to a national policy change, evaluation was limited to the impact on a specific clinical setting (table 2 ).

A study on the impact of mass public and health professional campaign on the ADR reporting conducted in Scotland showed an improvement in the reporting by members of public, however, the changes were reported to be insignificant [22]. Changes in the physician computer software systems implemented during the same period were deemed to have impacted on the observed positive changes. The comparator geography used in the evaluation was based outside of Scotland (table 2).

In summary, evidence from non-randomised studies showed that interventions involving financial incentives as a standalone or combined with other interventions types often yielded the biggest changes in the ADR reporting rates. Financial interventions reported between $59 \%$ and $855 \%$ increase in ADR reporting (Table 2). Similar to the findings from RCTs, face-to-face educational interventions showed greater impact on the number and quality of ADR reported than those not involving face-to-face interactions (table 2). Limited impact was reported around the impact of policy interventions. Pharmacovigilance activities aimed at patients were able to produce limited changes in reporting practices.

\subsection{Discussion}

Spontaneous ADR reporting is key to improving the post-marketing safety of medicines and it is imperative to identify essential features of successful interventions that can be adopted widely. This is the first systematic review incorporating a meta-analysis of the impact of interventions to improve the quality and quantity of spontaneous ADR reporting considering both healthcare professionals and patients. A total of 28 studies were included in the review of which none of the studies satisfied all quality criteria. Most of the studies were small scale studies conducted within one specific hospital, clinical speciality or a region. There was a lack of a high quality large scale, multi-centre RCTs or pragmatic study designs. Although seven studies used RCT designs, none were assessed to have a low risk of bias. Contamination was likely to exist given communications amongst healthcare professionals across study settings and geography. 
A total of 14 included studies in this systematic review did not include any control group. These were often single arm before and after study designs and the results of these studies are less likely to be transferable to other settings. Where control groups were used, data were often collected on the total number and nature of ADRs from other geographical areas or other healthcare settings. There was often a lack of adequate data on the demographics, clinical characteristics and baseline awareness of spontaneous ADR reporting amongst participants.

Most of the included studies included educational interventions to improve ADR reporting. A variety of educational methods were used including reminders, face to face educational sessions and newsletters. While most of these studies were reported to have improved ADR reporting, there was a lack of long-term follow up of the outcomes. The clusterrandomised controlled trials included in the study reported that the impact of interventions observed by the difference in the intervention and control group in the ADR reporting rate lasted for only 12 months after which such difference was no longer significant. While transient impact is easy to realise, sustainability around change in behaviours is often difficult to achieve [45-48]. Interventions that have been designed with implementation in mind from the outset face least barriers to implementation. Capacity building, ongoing monitoring and evaluation and addressing political, contextual and behavioural barriers to implementation have been identified as key factors that can promote sustainability [46].

\subsection{Implications for practice and research}

While a number of evaluations were included in the systematic review, they only represented a very small number of countries. There is a scope to improve spontaneous $A D R$ reporting in middle and low-and-middle income countries (LMIC) given the high contribution to global burden of diseases and increasing medicines use within those regions. Unique barriers may exist in LMICs which includes lack of a non-blame culture and professional hierarchy [24]. Hence in such settings, educational interventions alone may not be sufficient in changing practice.

There is a scope to include community pharmacy, particularly to improve ADR reporting by patients. Community pharmacies are well distributed geographically and are easily accessible by population. For example in England, over $90 \%$ of population in England live within a 20-minutes' walk to a community pharmacy and they are well situated to promote ADR reporting by patients $[49,50]$. Only five included studies used community pharmacy based interventions to improve ADR reporting, of which one only aimed to promote ADR reporting by patients. There is a scope for interventions aimed at patients to be developed, 
implemented and evaluated. Over a 100 countries have now provisions for ADR reporting by patients [51]. Despite this, a very low awareness amongst patients about their eligibility to report ADRs in eligible countries exist [52].

Interventions as well as outcomes measurement needs to be sustained over time. Continuing professional development models needs to be in place instead of one-off training events. Studies need to build needs assessment and implementation plans as part of the intervention development to promote sustainability.

There was a lack of consideration of behavioural theories in intervention development. There is an accumulation of evidence that theory based interventions are more likely to yield positive and sustainable results compared to pragmatic approaches. There is therefore a need for a well-designed, systematic and comprehensive study of a theoretically derived intervention aiming to optimize ADR reporting by health professionals and patients. The Medical Research Council Framework of Complex Interventions in the UK advises the use of theory and exploratory studies to identify barriers to change while developing complex interventions [53]. It is imperative that future interventions utilise appropriate theories to maximise the success of interventions. These include the use of theoretical domains framework (TDF) [54] and behaviour change taxonomy (BCT) [55]. The various interacting components in behaviour change research makes them challenging to identify the active, effective components within interventions and for others to replicate them. The included studies in these systematic reviews often tend to report mean changes in ADR reporting rates across all participants. It will be worth considering the low or the non-reporters and developing and targeting active ingredients of the interventions to focus on the low and non-reporters.

\subsection{CONCLUSIONS}

The limited evidence showed that active interventions involving face to face educational approaches, financial incentives and electronic features targeted at healthcare professionals could improve ADR reporting. However, the results need to be interpreted cautiously given the short term evaluation outcomes, dominance of observational designs and low quality of included studies. While observational studies are allow pragmatic approach to undertaking pharmacovigilance interventional studies, there is a need to develop and test theory based interventions through fully powered randomised controlled trial design, particularly those including patients. Moreover, there is a need for interventions to be developed and tested in countries low-and-middle income countries.

\section{Expert opinion}


Most of the currently available interventional research studies in relation to improving ADR reporting have relied on educational interventions with measurements of transient outcomes. Future studies need evidence base from LMICs, particularly in relation to addressing policy level, professional, organisational and cultural barriers to spontaneous ADR reporting. While global policy changes allowing patients to report spontaneous ADRs have been welcome, research to capture impact and facilitators of greater patient involvement needs to be undertaken through the use of behaviour change theories.

\section{References}

1. World Health Organization. Safety of Medicines - A Guide to Detecting and Reporting Adverse Drug Reactions - Why Health Professionals Need to Take Action. https://apps.who.int/medicinedocs/en/d/Jh2992e/2.html. Accessed 28 June 2020.

2. Oscanoa TJ, Lizaraso F, Carvajal A. Hospital admissions due to adverse drug reactions in the elderly. A meta-analysis. Eur J Clin Pharmcol. 2017; 173(6):759-70.

3. Vilhelmsson A. Consumer narratives in ADR reporting: an important aspect of public health? Experiences from reports to a Swedish consumer organization. Front Pub Health. 2015; $1: 3: 211$.

4. Sultana J, Cutroneo P, Trifirò G. Clinical and economic burden of adverse drug reactions. J Pharmcol Pharmacotherp. 2013;4(Suppl1):S73.

5. Hazell L, Shakir SA. Under-reporting of adverse drug reactions: a systematic review. Drug Saf. 2006;29(5):385-96.

6. Molokhia M, Tanna S. Bell D. Improving reporting of adverse drug reactions: systematic review. Clinical Epidem. 2009, 1: 75.

7. De Angelis A, Colaceci S, Giusti A, et al.. Factors that condition the spontaneous reporting of adverse drug reactions among nurses: an integrative review. Journal Nurs Manage. 2016; 24(2):151-163.

8. World Health Organization. Reporting and learning systems for medication errors: the role of pharmacovigilance centers, 2014. Available at: http://apps.who.int/medic inedo cs/documents/s2162 5en/s2162 5en.pdf. Accessed 10 February 2020.

9. Gonzalez-Gonzalez C, Lopez-Gonzalez E, Herdeiro MT, Figueiras A. Strategies to improve adverse drug reaction reporting: a critical and systematic review. Drug Saf 2013. $1: 36(5): 317-28$.

10. Cochrane Higgins JPT, Green S, eds. Cochrane Handbook for Systematic Reviews of Interventions, Version 5.0.0. The Cochrane Collaboration; 2011. Accessed at www.cochranehandbook.org. [Accessed 10 July 2020].

11. Moher D, Shamseer $L$, Clarke $M$ et al. Preferred reporting items for systematic review and meta-analysis protocols (PRISMA-P) 2015 statement. Systematic Rev. 2015;4[1]:1.

12. Paudyal V, Al-Hamid H, Jalal Z, et al.. Effectiveness of interventions to improve spontaneous reporting of adverse drug reactions: systematic review and meta-analysis. PROSPERO 2019 CRD42019162209 Available

At: https://www.crd.york.ac.uk/prospero/display_record.php?ID=CRD42019162209 [Accessed July 2020].

13. Higgins JP, Altman DG, Gøtzsche PC, et al. The Cochrane Collaboration's tool for assessing risk of bias in randomised trials. BMJ. 2011;343:d5928.

14. Critical appraisal skills programme (CASP). CASP Checklist. Available from: http://www.casp-uk.net/casp-tools-checklists. Accessed 01 July 2020.

15. Cochrane Uk. How to read a forest plot? https://uk.cochrane.org/news/how-read-forestplot. Accessed 01 July 2020

16. Greenland S. A critical look at some popular meta-analytic methods.Am J Epidemiol. 1994 Aug $1 ; 140(3): 290-6$. 
17. Ali S, Egunsola O, Al-Dossari DS, et al. Adverse drug reaction reporting in a large tertiary hospital in Saudi Arabia: results of an incentive strategy. Ther Adv Drug Saf. 2018;9(10):585-90.

18. Avong $\mathrm{YK}$, Jatau B, Gurumnaan R, et al. Addressing the under-reporting of adverse drug reactions in public health programs controlling HIV/AIDS, Tuberculosis and Malaria: A prospective cohort study. PloS One. 2018;13(8).

19. Roy R, Ma J. Impact of a policy change on pharmacists' reporting of adverse drug reactions. The Can J Hosp Pharm. 2018;71(4):227.

20. Chang $\mathrm{F}, \mathrm{Xi} Y$, Zhao J, et al. A time series analysis of the effects of financial incentives and mandatory clinical applications as interventions to improve spontaneous adverse drug reaction reporting by hospital medical staff in China. J Eval Clin Prac. 2017;23(6):1316-21.

21. Fang $H$, Lin $X$, Zhang J, et al. Multifaceted interventions for improving spontaneous reporting of adverse drug reactions in a general hospital in China. BMC Pharmacol Toxicol. 2017; $1: 18(1): 49$.

22. Aldeyab MA, Noble SC, Cuthbert M, et al. Assessment of the impact of the Scottish public health campaign on patient reporting of adverse drug reactions. Drugs \& Thearp Persp. 2016; 1:32(5):209-18.

23. Ríos OM, Gutiérrez LJ, Talavera JO, et al. A comprehensive intervention for adverse drug reactions identification and reporting in a pediatric emergency department. Int J Clin Pharm. 2016; 1:38(1):80-7.

24. Srikanth MS, Adepu R, Nagaraj S. Impact of an educational intervention on knowledge, attitude, and practices of urban community pharmacists towards adverse drug reaction reporting in a South India city. Asian J Pharm Clin Res. 2016;9:140-4.

25. Lopez-Gonzalez E, Herdeiro MT, Piñeiro-Lamas M et al. Effect of an educational intervention to improve adverse drug reaction reporting in physicians: a cluster randomized controlled trial. Drug Saf. 2015;1:38(2):189-96.

26. Biagi C, Montanaro N, Buccellato $E$, et al. Underreporting in pharmacovigilance: an intervention for Italian GPs (Emilia-Romagna region). Eur J Clin Pharmcol. 2013; $1: 69(2): 237-44$.

27. Herdeiro MT, Ribeiro-Vaz I, Ferreira M, et al. Workshop-and Telephone-Based Interventions to Improve Adverse Drug Reaction Reporting. Drug Saf. 2012;1:35(8):655-65.

28. Ribeiro-Vaz, Santos C, da Costa-Pereira A, et al. Promoting Spontaneous Adverse Drug Reaction Reporting in Hospitals Using a Hyperlink to the Online Reporting Form. Drug Saf. 2012; 1:35(5):387-94.

29. Gerritsen $R$, Faddegon $H$, Dijkers $F$, et al. Effectiveness of pharmacovigilance training of general practitioners. Drug Saf. 2011;1:34(9):755-62.

30. Johansson ML, Hägg S, Wallerstedt SM. Impact of information letters on the reporting rate of adverse drug reactions and the quality of the reports: a randomized controlled study. BMC Clin Pharmacol. 2011;1:14.

31. Ribeiro-Vaz I, Herdeiro MT, Polónia J et al. Strategies to increase the sensitivity of pharmacovigilance in Portugal. Revista de Saude Publica. 2011;12:45:129-35.

32. Gony M, Badie K, Sommet A, et al. Improving adverse drug reaction reporting in hospitals. Drug Saf. 2010; 1:33(5):409-16.

33. Yen $\mathrm{YH}$, Kuo LN, Hsu MH, et al. Evaluation of the electronic adverse drug event management system. J Exper Clin Med. 2010;1:2(6):287-91.

34. Johansson ML, Brunlöf G, Edward C, et al. Effects of e-mails containing ADR information and a current case report on ADR reporting rate and quality of reports. Eur J Clin Pharmacol. 2009; 1:65(5):511-4.

35. Ortega A, Aguinagalde A, Lacasa C et al. Efficacy of an adverse drug reaction electronic reporting system integrated into a hospital information system. Annals Pharmacother. $2008 ; 42(10): 1491-6$.

36. Pedrós C, Vallano A, Cereza G, et al. An intervention to improve spontaneous adverse drug reaction reporting by hospital physicians. Drug Saf. 2009; 1:32(1):77-83.

37. Tabali $M$, Jeschke $E$, Bockelbrink $A$, et al. Educational intervention to improve physician reporting of adverse drug reactions (ADRs) in a primary care setting in complementary and alternative medicine. BMC Public Health. 2009; 1:9(1):274. 
38. Herdeiro MT, Polónia J, Gestal-Otero JJ, et al. Improving the reporting of adverse drug reactions. Drug Saf. 2008; 1:31(4):335-44.

39. Bäckström M, Mjörndal T. A small economic inducement to stimulate increased reporting of adverse drug reactions a way of dealing with an old problem? Eur J Clin Pharmacol. $2006 ; 1: 62(5): 381-5$.

40. Figueiras $A$, Herdeiro MT, Polónia J, et al. An educational intervention to improve physician reporting of adverse drug reactions: a cluster-randomized controlled trial. JAMA2. 006; 6:296(9):1086-93.

41. Bracchi RC, Houghton J, Woods FJ, et al. A distance-learning programme in pharmacovigilance linked to educational credits is associated with improved reporting of suspected adverse drug reactions via the UK yellow card scheme. $\mathrm{Br} \mathrm{J}$ Clin Pharmacol. 2005;60(2):221-3.

42. Lata PF, Mainhardt M, Johnson CA. Impact of nurse case manager-pharmacist collaboration on adverse-drug-event reporting. Am J Health-System Pharm. 2004;1:61(5):483-7.

43. Castel JM, Figueras A, Pedrós $C$, et al. Stimulating adverse drug reaction reporting. Drug Saf. 2003; $1: 26(14): 1049-55$.

44. Bäckström M, Mjörndal T, Dahlqvist R. Spontaneous reporting of adverse drug reactions by nurses. Pharmacoepid Drug Saf. 2002;11(8):647-50.

45. Paudyal V, Hansford D, Cunningham S, Stewart D. Pharmacists' perceived integration into practice of over-the-counter simvastatin five years post reclassification. Int J Pharm Prac. 2012;1:34(5):733-8.

46. Shelton RC, Cooper BR, Stirman SW. The sustainability of evidence-based interventions and practices in public health and health care. Ann Rev Pub Health. 2018;1:39:55-76.

47. Todd A, Copeland A, Husband A, Kasim A, Bambra C. The positive pharmacy care law: an area-level analysis of the relationship between community pharmacy distribution, urbanity and social deprivation in England. BMJ Open. 2014;1:4(8):e005764.

48. Stewart D, MacLure K, Paudyal V, Hughes C, Courtenay M, McLay J. Non-medical prescribers and pharmacovigilance: participation, competence and future needs. Int J Clin Pharm. 2013;1:35(2):268-74.

49. Matos C, Härmark L, van Hunsel F. Patient reporting of adverse drug reactions: an international survey of national competent authorities' views and needs. Drug Saf. 2016;39(11):1105-16.

50. Al Dweik $R$, Stacey $D$, Kohen $D$ et al.. Factors affecting patient reporting of adverse drug reactions: a systematic review. $\mathrm{Br}$ J Clin Pharmacol 2017;83(4):875-83.

51. Craig P, Dieppe $P$, Macintyre $S$, et al.. Developing and evaluating complex interventions: the new Medical Research Council guidance. BMJ 2008; 29;337:a1655.

52. Atkins L, Francis J, Islam R, et al.. A guide to using the Theoretical Domains Framework of behaviour change to investigate implementation problems. Implement Sci. 2017 Dec;12(1): 77 .

53. Michie S, Richardson M, Johnston M, et al The Behavior Change Technique Taxonomy (v1) of 93 hierarchically clustered techniques: building an international consensus for the reporting of behavior change interventions, Ann Behav Med. 2013;46(1): 81-95. 
Table 1: Characteristics of included studies

\begin{tabular}{|c|c|c|c|c|c|c|c|c|c|}
\hline $\begin{array}{l}\text { Study } \\
\text { (author } \\
\text { and year) }\end{array}$ & Aim & Country & Study design & $\begin{array}{l}\text { Study } \\
\text { setting }\end{array}$ & $\begin{array}{l}\text { Participants/targ } \\
\text { et population } \\
\text { intervention } \\
\text { including number } \\
\text { of participants } \\
\text { where stated }\end{array}$ & $\begin{array}{l}\text { Participants } / t \\
\text { arget } \\
\text { population } \\
\text { control }\end{array}$ & $\begin{array}{l}\text { Follow up } \\
\text { duration }\end{array}$ & Study outcome(s) & $\begin{array}{c}\text { ADR } \\
\text { classification }\end{array}$ \\
\hline $\begin{array}{l}\text { Ali et al. } \\
2018^{17}\end{array}$ & $\begin{array}{l}\text { To describe the reporting of ADRs in a } \\
\text { tertiary hospital and determine the effect } \\
\text { of incentives to healthcare professionals } \\
\text { on ADR reporting }\end{array}$ & $\begin{array}{l}\text { Saudi } \\
\text { Arabia }\end{array}$ & $\begin{array}{l}\text { Pre-post } \\
\text { observational } \\
\text { study/ time } \\
\text { series }\end{array}$ & $\begin{array}{l}\text { A tertiary } \\
\text { hospital }\end{array}$ & $\begin{array}{l}\text { Patients, } \\
\text { pharmacists, } \\
\text { physicians, nurses } \\
\text { and others ( } \mathrm{n} \\
\text { unclear) }\end{array}$ & $\begin{array}{l}\text { No control } \\
\text { group }\end{array}$ & 12 months & $\begin{array}{l}\text { Quality and quantity } \\
\text { of ADRs reported }\end{array}$ & $\begin{array}{l}\text { Serious and non- } \\
\text { serious ADRs }\end{array}$ \\
\hline $\begin{array}{l}\text { Avong et } \\
\text { al. } 2018^{18}\end{array}$ & $\begin{array}{l}\text { To evaluate pharmacovigilance training } \\
\text { model that was designed } \\
\text { to improve the reporting of ADRs in public } \\
\text { health programs treating the Human } \\
\text { Immunodeficiency } \\
\text { Virus, tuberculosis and Malaria }\end{array}$ & Nigeria & $\begin{array}{l}\text { Pre-post } \\
\text { observational } \\
\text { study }\end{array}$ & $\begin{array}{l}\text { health } \\
\text { facilities and } \\
\text { institutions }\end{array}$ & $\begin{array}{l}\text { Nurses, physicians } \\
\text { and pharmacists } \\
(\mathrm{n}=55 \text { in total })\end{array}$ & $\begin{array}{l}\text { No control } \\
\text { group }\end{array}$ & 12 months & $\begin{array}{l}\text { Knowledge gained } \\
\text { and the number of } \\
\text { ADR reports } \\
\text { submitted }\end{array}$ & Not available \\
\hline $\begin{array}{l}\text { Roy, Ma } \\
2018^{19}\end{array}$ & $\begin{array}{l}\text { To determine whether ADR reporting } \\
\text { behaviours of pharmacists improved after } \\
\text { release of a revised policy on the reporting } \\
\text { of medication incidents }\end{array}$ & Canada & $\begin{array}{l}\text { Pre-post } \\
\text { observational } \\
\text { study }\end{array}$ & $\begin{array}{l}\text { Canadian } \\
\text { Forces } \\
\text { Health } \\
\text { Services } \\
\text { Group }\end{array}$ & 48 pharmacists & $\begin{array}{l}\text { No control } \\
\text { group }\end{array}$ & 3 months & $\begin{array}{l}\text { Quality and quantity } \\
\text { of ADRs reported }\end{array}$ & Not available \\
\hline $\begin{array}{l}\text { Chang et } \\
\text { al. } 2017^{20}\end{array}$ & $\begin{array}{l}\text { To assess the effectiveness of a financial } \\
\text { intervention for improving ADR reporting } \\
\text { by physicians in a hospital setting }\end{array}$ & China & $\begin{array}{l}\text { Ecological time } \\
\text { series study }\end{array}$ & $\begin{array}{l}\text { Tertiary care } \\
\text { university } \\
\text { hospital }\end{array}$ & $\begin{array}{l}\text { Physicians and } \\
\text { pharmacists ( } \mathrm{n} \\
\text { unclear) }\end{array}$ & $\begin{array}{l}\text { No control } \\
\text { group }\end{array}$ & $\begin{array}{l}\text { Time series } \\
\text { for eight } \\
\text { years }\end{array}$ & $\begin{array}{l}\text { Quantity and quality } \\
\text { (serious and new } \\
\text { ADRs) }\end{array}$ & $\begin{array}{l}\text { Total, general; } \\
\text { new; and serious }\end{array}$ \\
\hline $\begin{array}{l}\text { Fang et al. } \\
2017^{21}\end{array}$ & $\begin{array}{l}\text { To compare the spontaneous reporting } \\
\text { data collected under old and new } \\
\text { regulations }\end{array}$ & China & $\begin{array}{l}\text { Ecological time } \\
\text { series study }\end{array}$ & Hospital & $\begin{array}{l}\text { Physicians, clinical } \\
\text { pharmacists, and } \\
\text { nurses } \\
\text { (approximate } n= \\
\text { 943) }\end{array}$ & $\begin{array}{l}\text { No control } \\
\text { group }\end{array}$ & $\begin{array}{l}\text { Time series } \\
\text { for eleven } \\
\text { years }\end{array}$ & $\begin{array}{l}\text { Quantity of ADR } \\
\text { reports and } \\
\text { compliance with and } \\
\text { clinical utility of } \\
\text { reports }\end{array}$ & $\begin{array}{l}\text { Total, serious; and } \\
\text { general }\end{array}$ \\
\hline $\begin{array}{l}\text { Aldeyab et } \\
\text { al. } 2016^{22}\end{array}$ & $\begin{array}{l}\text { To assess patterns in reporting of ADRs } \\
\text { via the Yellow Card Scheme following a } \\
\text { Scottish community pharmacy patient } \\
\text { Yellow Card promotional campaign }\end{array}$ & $\begin{array}{l}\text { Scotland, } \\
\text { UK }\end{array}$ & $\begin{array}{l}\text { Ecological time } \\
\text { series study }\end{array}$ & $\begin{array}{l}\text { Healthcare } \\
\text { professionals } \\
\text { and patients }\end{array}$ & $\begin{array}{l}\text { All inhabitants of } \\
\text { Scotland }\end{array}$ & $\begin{array}{l}\text { All inhabitants } \\
\text { of the Northern } \\
\text { and Yorkshire }\end{array}$ & 12 months & $\begin{array}{l}\text { Number and quality } \\
\text { of ADR reporting }\end{array}$ & $\begin{array}{l}\text { Overall, total and } \\
\text { serious }\end{array}$ \\
\hline $\begin{array}{l}\text { Ríos et al. } \\
2016^{23}\end{array}$ & $\begin{array}{l}\text { To assess the effectiveness of a } \\
\text { pharmacist intervention in a tertiary care } \\
\text { paediatric hospital on ADR identification } \\
\text { and reporting }\end{array}$ & Mexico & $\begin{array}{l}\text { Quasi- } \\
\text { experimental, } \\
\text { pre-post test } \\
\text { study }\end{array}$ & $\begin{array}{l}\text { Paediatric } \\
\text { ED }\end{array}$ & $\begin{array}{l}62 \text { physicians based } \\
\text { at the emergency } \\
\text { department }\end{array}$ & $\begin{array}{l}\text { No control } \\
\text { group }\end{array}$ & 6 months & $\begin{array}{l}\text { Total ADRs, those } \\
\text { correctly identified \& } \\
\text { number of s } \\
\text { reported }\end{array}$ & Not classified \\
\hline $\begin{array}{l}\text { Srikanth et } \\
\text { al. } 2016^{24}\end{array}$ & $\begin{array}{l}\text { To evaluate the impact of the educational } \\
\text { program on community pharmacist's } \\
\text { knowledge and perception toward ADR } \\
\text { reporting }\end{array}$ & India & $\begin{array}{l}\text { Prospective } \\
\text { interventional } \\
\text { study }\end{array}$ & $\begin{array}{l}\text { Community } \\
\text { pharmacies } \\
\text { in Mysore, } \\
\text { South India }\end{array}$ & $\begin{array}{l}26 \text { practising } \\
\text { community } \\
\text { pharmacists }\end{array}$ & $\begin{array}{l}\text { No control } \\
\text { group }\end{array}$ & Not stated & $\begin{array}{l}\text { Self-reported ADR } \\
\text { reporting practices }\end{array}$ & Not defined \\
\hline $\begin{array}{l}\text { Lopez- } \\
\text { Gonzalez } \\
\text { et al. } \\
2015^{25}\end{array}$ & $\begin{array}{l}\text { To assess the effect of an educational } \\
\text { intervention to improve the quantity and } \\
\text { relevance of physician-led spontaneous } \\
\text { ADR reporting }\end{array}$ & Spain & $\begin{array}{l}\text { Spatial, cluster } \\
\text { RCT }\end{array}$ & $\begin{array}{l}\text { Hospitals } \\
\text { and primary } \\
\text { care centres }\end{array}$ & 2,120 physicians & $\begin{array}{l}3,614 \\
\text { physicians }\end{array}$ & 8 months & $\begin{array}{l}\text { Number of reports } \\
\text { and the nature of } \\
\text { ADRs }\end{array}$ & $\begin{array}{l}\text { serious; } \\
\text { unexpected; and } \\
\text { high causality } \\
\text { (probable) }\end{array}$ \\
\hline
\end{tabular}




\begin{tabular}{|c|c|c|c|c|c|c|c|c|c|}
\hline $\begin{array}{l}\text { Biagi et al. } \\
2013^{26}\end{array}$ & $\begin{array}{l}\text { To evaluate whether an e-mail-based } \\
\text { monthly drug safety newsletter sent to } \\
\text { GPs would affect the quality and quantity } \\
\text { of ADR reports }\end{array}$ & Italy & $\begin{array}{l}\text { Prospective } \\
\text { interventional } \\
\text { study }\end{array}$ & $\begin{array}{l}\text { GPs in three } \\
\text { local health } \\
\text { authorities }\end{array}$ & $\begin{array}{l}\text { All } 737 \text { GPs from } \\
\text { the } 3 \text { local health } \\
\text { authorities }\end{array}$ & $\begin{array}{l}\text { Pooled number } \\
\text { of ADR reports } \\
\text { from } 7 \text { other } \\
\text { regions }\end{array}$ & 10 months & $\begin{array}{l}\text { Number and quality } \\
\text { of reports }\end{array}$ & Not classified \\
\hline $\begin{array}{l}\text { Herdeiro et } \\
\text { al. } 2012^{27}\end{array}$ & $\begin{array}{l}\text { To evaluate the results of workshop and } \\
\text { telephone based educational interventions } \\
\text { on quantity, quality (relevance) and } \\
\text { duration of the effect of these } \\
\text { interventions }\end{array}$ & Portugal & $\begin{array}{l}\text { Cluster } \\
\text { randomised } \\
\text { controlled trial }\end{array}$ & $\begin{array}{l}25 \text { hospitals } \\
\text { in the } \\
\text { Northern } \\
\text { region of } \\
\text { Portugal }\end{array}$ & $\begin{array}{l}1388 \text { physicians } \\
\text { from } 4 \text { spatial } \\
\text { clusters }\end{array}$ & $\begin{array}{l}5063 \\
\text { physicians from } \\
11 \text { spatial } \\
\text { clusters }\end{array}$ & 0-20months & $\begin{array}{l}\text { Reporting quantity; } \\
\text { and reporting } \\
\text { relevance }\end{array}$ & $\begin{array}{l}\text { Serious; definitive } \\
\text { or probable; and } \\
\text { unexpected }\end{array}$ \\
\hline $\begin{array}{l}\text { Ribeiro- } \\
\text { Vaz et al. } \\
2012^{28}\end{array}$ & $\begin{array}{l}\text { To evaluate the impact of adding } \\
\text { hyperlinks to an online ADR reporting form } \\
\text { to hospitals' electronic patient records on } \\
\text { the number of spontaneous ADR reports }\end{array}$ & Portugal & $\begin{array}{l}\text { Ecological } \\
\text { study }\end{array}$ & $\begin{array}{l}27 \text { hospitals } \\
\text { in Northern } \\
\text { Portugal }\end{array}$ & $\begin{array}{l}\text { All staff in } 16 \\
\text { hospitals) }\end{array}$ & $\begin{array}{l}\text { All staff in } 11 \\
\text { hospitals }\end{array}$ & 31 months & $\begin{array}{l}\text { Number of reports, } \\
\text { seriousness of the } \\
\text { ADRs }\end{array}$ & $\begin{array}{l}\text { Categorised into: } \\
\text { total; serious or } \\
\text { non-serious; and } \\
\text { previously known }\end{array}$ \\
\hline $\begin{array}{l}\text { Gerritsen } \\
\text { et al. } \\
2011^{29}\end{array}$ & $\begin{array}{l}\text { To establish whether the use of a practice- } \\
\text { based pharmacovigilance training method } \\
\text { during GP training leads to an increase of } \\
\text { reported ADRs after completion of this } \\
\text { training, compared with a lecture-based } \\
\text { method }\end{array}$ & $\begin{array}{l}\text { Netherland } \\
\mathrm{s}\end{array}$ & $\begin{array}{l}\text { Retrospective } \\
\text { cohort study }\end{array}$ & $\begin{array}{l}\text { General } \\
\text { practice }\end{array}$ & $\begin{array}{l}\text { Lecture-based: } 135 \\
\text { GPs; Practice- } \\
\text { based: } 124 \text { GPs }\end{array}$ & $\begin{array}{l}\text { No control } \\
\text { group }\end{array}$ & $\begin{array}{l}\text { Mean }=431 \\
\text { months }\end{array}$ & $\begin{array}{l}\text { Number of reports, } \\
\text { quality } \\
\text { (documentation } \\
\text { level of the reports) }\end{array}$ & $\begin{array}{l}\text { Labelled; and } \\
\text { unlabelled }\end{array}$ \\
\hline $\begin{array}{l}\text { Johansson } \\
\text { et al. } \\
2011^{30}\end{array}$ & $\begin{array}{l}\text { To evaluate if repeated one-page ADR } \\
\text { information letters affect the reporting } \\
\text { rate of ADRs, and the quality of the ADR } \\
\text { reports }\end{array}$ & Sweden & $\begin{array}{l}\text { Randomised } \\
\text { controlled } \\
\text { study }\end{array}$ & $\begin{array}{l}\text { Primary } \\
\text { healthcare } \\
\text { units }\end{array}$ & $\begin{array}{l}\text { GPs and nurses at } \\
77 \text { primary } \\
\text { healthcare units }\end{array}$ & $\begin{array}{l}\text { GPs and } \\
\text { nurses) at } 74 \\
\text { primary } \\
\text { healthcare } \\
\text { units }\end{array}$ & 12 months & $\begin{array}{l}\text { Number and quality } \\
\text { of reports }\end{array}$ & $\begin{array}{l}\text { Serious; } \\
\text { unexpected; new } \\
\text { drug and not } \\
\text { common; all other }\end{array}$ \\
\hline $\begin{array}{l}\text { Ribeiro- } \\
\text { Vaz et al. } \\
2011^{31}\end{array}$ & $\begin{array}{l}\text { To evaluate the results of an educational } \\
\text { intervention used to improve the number } \\
\text { and relevance of reports of ADRs }\end{array}$ & Portugal & $\begin{array}{l}\text { Cluster } \\
\text { randomised } \\
\text { controlled trial }\end{array}$ & $\begin{array}{l}\text { Community } \\
\text { and hospital } \\
\text { pharmacy }\end{array}$ & $\begin{array}{l}\text { All pharmacists in } 4 \\
\text { cluster groups } \\
\text { ( } n=364 \text {, telephone } \\
\text { interviews, } n=261 ; \\
\text { workshop, } n=103 \text { ) }\end{array}$ & $\begin{array}{l}\text { All pharmacists } \\
\text { in } 11 \text { cluster } \\
\text { groups } \\
(n=1103)\end{array}$ & 20 months & $\begin{array}{l}\text { Number and Quality } \\
\text { of reports }\end{array}$ & $\begin{array}{l}\text { Classified into: } \\
\text { total; severe; high } \\
\text { level of } \\
\text { probability; } \\
\text { unexpected }\end{array}$ \\
\hline $\begin{array}{l}\text { Gony et al. } \\
2010^{32}\end{array}$ & $\begin{array}{l}\text { To assess the effect of regular visits of a } \\
\text { Clinical Research Assistant on the } \\
\text { improvement of ADR reporting in non- } \\
\text { university hospitals }\end{array}$ & France & $\begin{array}{l}\text { Longitudinal } \\
\text { study }\end{array}$ & $\begin{array}{l}\text { Non- } \\
\text { university } \\
\text { hospitals } \\
\text { within three } \\
\text { areas }\end{array}$ & $\begin{array}{l}\text { All healthcare staff } \\
\text { within two regions }\end{array}$ & $\begin{array}{l}\text { All healthcare } \\
\text { staff within one } \\
\text { region }\end{array}$ & $0-3$ years & $\begin{array}{l}\text { The total reporting } \\
\text { rate and \%of serious } \\
\text { ADRs, characteristic } \\
\text { of ADRs }\end{array}$ & $\begin{array}{l}\text { Total, } \\
\text { spontaneous; } \\
\text { solicited, and } \\
\text { serious }\end{array}$ \\
\hline $\begin{array}{l}\text { Yen et al. } \\
2010^{33}\end{array}$ & $\begin{array}{l}\text { To compare the efficiency and influence of } \\
\text { an electronic ADR management system } \\
\text { with a traditional working model at a } \\
\text { medical centre }\end{array}$ & Taiwan & $\begin{array}{l}\text { Ecological time } \\
\text { series study }\end{array}$ & $\begin{array}{l}\text { Taipei } \\
\text { Medical } \\
\text { University } \\
\text { Wan Fang } \\
\text { Hospital }\end{array}$ & $\begin{array}{l}\text { All healthcare staff } \\
\text { at Taipei Medical } \\
\text { University - Wan } \\
\text { Fang Hospital }\end{array}$ & $\begin{array}{l}\text { No control } \\
\text { group }\end{array}$ & $\begin{array}{l}\text { Time series } \\
\text { for } 6 \text { years }\end{array}$ & $\begin{array}{l}\text { Number of ADR } \\
\text { reports }\end{array}$ & $\begin{array}{l}\text { Classified into: } \\
\text { total; minor; } \\
\text { moderate; severe; } \\
\text { fatal }\end{array}$ \\
\hline $\begin{array}{l}\text { Johansson } \\
\text { et al. } \\
2009^{34}\end{array}$ & $\begin{array}{l}\text { To evaluate whether repeated e-mails with } \\
\text { attachments containing ADR information } \\
\text { can affect the reporting of ADRs and the } \\
\text { quality of the ADR reports }\end{array}$ & Sweden & $\begin{array}{l}\text { Randomised } \\
\text { controlled } \\
\text { study }\end{array}$ & $\begin{array}{l}\text { Primary } \\
\text { healthcare } \\
\text { units }\end{array}$ & $\begin{array}{l}\text { Staff in } 59 \\
\text { healthcare units }\end{array}$ & $\begin{array}{l}58 \text { healthcare } \\
\text { units }\end{array}$ & 12 months & $\begin{array}{l}\text { The total number of } \\
\text {; quality of ADRs }\end{array}$ & $\begin{array}{l}\text { Serious; } \\
\text { unexpected (not in } \\
\text { SPC); new }(<2 \\
\text { years on the } \\
\text { market) and not } \\
\text { common; and all } \\
\text { other reports }\end{array}$ \\
\hline
\end{tabular}




\begin{tabular}{|c|c|c|c|c|c|c|c|c|c|}
\hline $\begin{array}{l}\text { Pedrós et } \\
\text { al. } 2009^{36}\end{array}$ & $\begin{array}{l}\text { To assess the effectiveness of a } \\
\text { multifaceted intervention based on } \\
\text { healthcare management agreements for } \\
\text { improving spontaneous reporting of ADRs } \\
\text { by physicians in a hospital setting }\end{array}$ & Spain & $\begin{array}{l}\text { Time series } \\
\text { analysis }\end{array}$ & $\begin{array}{l}\text { A tertiary } \\
\text { care hospital }\end{array}$ & $\begin{array}{l}\text { All physicians at the } \\
\text { tertiary care } \\
\text { hospital }\end{array}$ & $\begin{array}{l}\text { No control } \\
\text { group }\end{array}$ & 3 years & $\begin{array}{l}\text { Total number of } \\
\text { reports; seriousness } \\
\text { of reports; and } \\
\text { reports of new drugs } \\
\text { causing }\end{array}$ & $\begin{array}{l}\text { Serious ; } \\
\text { unexpected ; and } \\
\text { associated with } \\
\text { new drugs }\end{array}$ \\
\hline $\begin{array}{l}\text { Tabali et } \\
\text { al. } 2009^{37}\end{array}$ & $\begin{array}{l}\text { To evaluate the impact of an educational } \\
\text { intervention and monitoring programme } \\
\text { designed to improve physician reporting of } \\
\text { ADRs in a primary care setting }\end{array}$ & Germany & $\begin{array}{l}\text { Prospective } \\
\text { multicentre } \\
\text { observational } \\
\text { study }\end{array}$ & Primary care & $\begin{array}{l}38 \text { primary care } \\
\text { physicians } \\
\text { specialised in CAM }\end{array}$ & $\begin{array}{l}\text { No control } \\
\text { group }\end{array}$ & 21 months & $\begin{array}{l}\text { Number, quality and } \\
\text { completeness of } \\
\text { reports }\end{array}$ & $\begin{array}{l}\text { Seriousness } \\
\text { (degree of) or } \\
\text { non-serious, } \\
\text { causality }\end{array}$ \\
\hline $\begin{array}{l}\text { Herdeiro et } \\
\text { al. } 2008^{38}\end{array}$ & $\begin{array}{l}\text { To evaluate the effectiveness of } \\
\text { educational outreach visits aimed at } \\
\text { improving ADR reporting by pharmacists }\end{array}$ & Portugal & $\begin{array}{l}\text { Cluster } \\
\text { randomised } \\
\text { controlled trial }\end{array}$ & $\begin{array}{l}\text { Hospital and } \\
\text { community } \\
\text { pharmacies }\end{array}$ & 342 pharmacists & $\begin{array}{l}1091 \\
\text { pharmacists }\end{array}$ & 16 months & $\begin{array}{l}\text { Total; serious; } \\
\text { unexpected; high- } \\
\text { causality; and new } \\
\text { drug related }\end{array}$ & $\begin{array}{l}\text { Total ADRs; } \\
\text { serious s; } \\
\text { unexpected s; } \\
\text { high-causality s; } \\
\text { and new drug } \\
\text { related s }\end{array}$ \\
\hline $\begin{array}{l}\text { Ortega et } \\
\text { al. } 2008^{35}\end{array}$ & $\begin{array}{l}\text { To analyse the efficacy of an electronic } \\
\text { ADR reporting tool, make improvements to } \\
\text { increase ADR reporting, and evaluate the } \\
\text { impact of these improvements }\end{array}$ & Spain & $\begin{array}{l}\text { Time series } \\
\text { analysis }\end{array}$ & $\begin{array}{l}\text { A private } \\
\text { tertiary care } \\
\text { hospital }\end{array}$ & $\begin{array}{l}\text { All physicinas, } \\
\text { pharmacists and } \\
\text { nurses at the } \\
\text { hospital }\end{array}$ & $\begin{array}{l}\text { No control } \\
\text { group }\end{array}$ & 1 year & $\begin{array}{l}\text { Total number of } \\
\text { reports }\end{array}$ & $\begin{array}{l}\text { Classified into: } \\
\text { total number of } \\
\text { reports }\end{array}$ \\
\hline $\begin{array}{l}\text { Bäckström } \\
\text { et al. } \\
2006^{39}\end{array}$ & $\begin{array}{l}\text { To assess the effect of a small economic } \\
\text { inducement on the rate of spontaneous } \\
\text { reporting of ADRs and the attitudes of } \\
\text { general practitioners and physicians } \\
\text { towards reporting of ADRs }\end{array}$ & Sweden & $\begin{array}{l}\text { Prospective } \\
\text { interventional } \\
\text { study }\end{array}$ & $\begin{array}{l}\text { Hospitals } \\
\text { and primary } \\
\text { care centres }\end{array}$ & Unclear & unclear & 6 months & $\begin{array}{l}\text { Number of reports; } \\
\text { quality and } \\
\text { seriousness of the } \\
\text { report }\end{array}$ & $\begin{array}{l}\text { Total, serious, and } \\
\text { suspected }\end{array}$ \\
\hline $\begin{array}{l}\text { Figueiras } \\
\text { et al. } \\
2006^{40}\end{array}$ & $\begin{array}{l}\text { To evaluate the effectiveness of } \\
\text { educational outreach visits for improving } \\
\text { ADR reporting by physicians }\end{array}$ & Portugal & $\begin{array}{l}\text { Cluster } \\
\text { randomised } \\
\text { controlled trial }\end{array}$ & $\begin{array}{l}\text { Hospitals } \\
\text { and } \\
\text { outpatient } \\
\text { centres }\end{array}$ & $\mathrm{n}=1388$ physicians & $\begin{array}{l}\mathrm{n}=5063 \\
\text { physicians }\end{array}$ & 16 months & $\begin{array}{l}\text { Quantity and quality } \\
\text { of reports }\end{array}$ & $\begin{array}{l}\text { All, serious, high } \\
\text { causality; } \\
\text { unexpected or } \\
\text { unlabelled; and } \\
\text { for new drugs }\end{array}$ \\
\hline $\begin{array}{l}\text { Bracchi et } \\
\text { al. } 2005^{41}\end{array}$ & $\begin{array}{l}\text { To investigate the effect of a distance- } \\
\text { learning package linked to educational } \\
\text { credits on the rate and quality of } \\
\text { spontaneous ADR reporting by general } \\
\text { practitioners and pharmacists in Wales }\end{array}$ & Wales, UK & $\begin{array}{l}\text { Prospective } \\
\text { interventional } \\
\text { study }\end{array}$ & $\begin{array}{l}\text { General } \\
\text { practices, } \\
\text { community } \\
\text { pharmacies }\end{array}$ & $\begin{array}{l}\text { Pharmacists } \\
(n=2039) \text { and GPs } \\
(n=1745)\end{array}$ & $\begin{array}{l}\text { The Northern } \\
\text { region of } \\
\text { England }\end{array}$ & $1-15$ months & $\begin{array}{l}\text { Rate and quality of } \\
\text { spontaneous reports }\end{array}$ & Total ADRs \\
\hline $\begin{array}{l}\text { Lata et al. } \\
2004^{42}\end{array}$ & $\begin{array}{l}\text { To determine the impact of the integration } \\
\text { of nurse case managers into the ADR } \\
\text { reporting system on ADR reports }\end{array}$ & USA & $\begin{array}{l}\text { Time series } \\
\text { analysis }\end{array}$ & $\begin{array}{l}\text { A small } \\
\text { community } \\
\text { hospital in } \\
\text { rural } \\
\text { Wisconsin }\end{array}$ & $\begin{array}{l}\text { All staff at the } \\
\text { community hospital } \\
\text { who could report } \\
\text { ADRs, especially } \\
\text { the nurse case } \\
\text { managers }\end{array}$ & $\begin{array}{l}\text { No control } \\
\text { group }\end{array}$ & 3 years & $\begin{array}{l}\text { Number of reports } \\
\text { and the number of } \\
\text { serious, possible, } \\
\text { and preventable }\end{array}$ & $\begin{array}{l}\text { Classified into: } \\
\text { total, serious, } \\
\text { possible, and } \\
\text { preventable }\end{array}$ \\
\hline $\begin{array}{l}\text { Castel et } \\
\text { al. } 2003^{43}\end{array}$ & $\begin{array}{l}\text { To measure the effect of the periodical } \\
\text { distribution of a bulletin on drug safety } \\
\text { issues and of including yellow cards in } \\
\text { prescription pads on the rate of ADR } \\
\text { reporting }\end{array}$ & Spain & $\begin{array}{l}\text { Time series } \\
\text { analysis }\end{array}$ & $\begin{array}{l}\text { All practising } \\
\text { physicians } \\
\text { within the } \\
\text { region }\end{array}$ & $\begin{array}{l}\text { All practising } \\
\text { physicians within } \\
\text { the catchment area } \\
\text { were included }\end{array}$ & $\begin{array}{l}\text { No control } \\
\text { group }\end{array}$ & $\begin{array}{l}\text { Time series } \\
\text { for } 13 \text { years }\end{array}$ & Total, reporting rate & $\begin{array}{l}\text { Total ADRs } \\
\text { reported and } \\
\text { reporting rate }\end{array}$ \\
\hline $\begin{array}{l}\text { Bäckström } \\
\text { et al. } \\
2002^{44}\end{array}$ & $\begin{array}{l}\text { To investigate whether trained nurses } \\
\text { could be a useful source for improving the } \\
\text { reporting rate of ADRs in Sweden }\end{array}$ & Sweden & $\begin{array}{l}\text { Prospective } \\
\text { interventional } \\
\text { study }\end{array}$ & $\begin{array}{l}\text { Geriatric } \\
\text { medicine } \\
\text { hospitals in } \\
\text { northern } \\
\text { Sweden }\end{array}$ & $\begin{array}{l}\text { All } 117 \text { nurses } \\
\text { working at the two } \\
\text { geriatric medicine } \\
\text { units }\end{array}$ & $\begin{array}{l}\text { All other } 50 \\
\text { geriatric } \\
\text { departments in } \\
\text { hospitals in } \\
\text { Sweden }\end{array}$ & 12 months & reporting rate & $\begin{array}{l}\text { Labelled/unlabelle } \\
\text { d; and serious }\end{array}$ \\
\hline
\end{tabular}


Table 2: Intervention outcomes

\begin{tabular}{|c|c|c|c|c|c|c|c|c|c|c|c|}
\hline \multirow[t]{2}{*}{ Study ID } & \multirow[t]{2}{*}{$\begin{array}{l}\text { Nature of } \\
\text { intervention }\end{array}$} & \multirow[t]{2}{*}{$\begin{array}{l}\text { Details of } \\
\text { intervention }\end{array}$} & \multirow{2}{*}{$\begin{array}{l}\text { What did the } \\
\text { control group } \\
\text { receive? }\end{array}$} & \multirow{2}{*}{$\begin{array}{l}\text { Any clinical } \\
\text { area of } \\
\text { focus }\end{array}$} & \multirow[t]{2}{*}{$\begin{array}{l}\text { Respons } \\
\text { e rate }\end{array}$} & \multicolumn{2}{|c|}{$\begin{array}{l}\text { ADR reporting pre- } \\
\text { intervention (baseline) }\end{array}$} & \multicolumn{2}{|c|}{$\begin{array}{l}\text { ADR reporting post intervention- } \\
\text { all time points }\end{array}$} & \multirow{2}{*}{$\begin{array}{l}\text { \% change post } \\
\text { intervention } \\
\text { and p values } \\
\text { where reported }\end{array}$} & \multirow[t]{2}{*}{$\begin{array}{l}\text { Change in quality } \\
\text { of ADR reporting }\end{array}$} \\
\hline & & & & & & control & Intervention & Control & Intervention & & \\
\hline $\begin{array}{l}\text { Ali et al. } \\
2018^{17}\end{array}$ & Financial & $\begin{array}{l}\text { Reward } \\
\text { system, including } \\
\text { public } \\
\text { commendation and } \\
\text { award }\end{array}$ & $\mathrm{N} / \mathrm{A}$ & $\begin{array}{l}\text { Not } \\
\text { specified }\end{array}$ & $\begin{array}{l}\text { Not } \\
\text { reported- }\end{array}$ & - & 167 reports & & 800 reports & $379 \%$ & $\begin{array}{l}\text { Increase in reporting } \\
\text { of the serious ADRs }\end{array}$ \\
\hline $\begin{array}{l}\text { Chang et } \\
\text { al. } 2017^{20}\end{array}$ & Financial & $\begin{array}{l}\text { First intervention: } \\
\text { Financial incentives } \\
\text { including penalty. } \\
\text { Second } \\
\text { intervention: } \\
\text { Financial incentive } \\
\text { and strict } \\
\text { regulations for } \\
\text { antimicrobial } \\
\text { agents }\end{array}$ & N/A & $\begin{array}{l}\text { No specific } \\
\text { area. } \\
\text { Antimicrobia } \\
\text { Is }\end{array}$ & - & - & $\begin{array}{l}\text { Median per } \\
\text { month: } \\
3.56 \pm 3.60 \\
3.56 \pm 3.60 \\
\text { (95\% CI 2.42- } \\
4.75) \text {, and per } \\
\text { year was } 29 \\
\text { (range 27-72) }\end{array}$ & - & $\begin{array}{l}\text { Post first } \\
\text { intervention: } \\
21 \pm 13(95 \% \mathrm{CI} \\
16.97-25.80) \text { per } \\
\text { month, 277 per } \\
\text { year. Post second } \\
\text { intervention: } \\
56 \pm 20(95 \% \mathrm{CI} \\
48.81-62.17) \text { per } \\
\text { month, } 666 \text { per } \\
\text { year }\end{array}$ & $\begin{array}{l}\text { Financial }+855 \% \\
\text { Financial plus } \\
\text { regulation } \\
+2197 \%\end{array}$ & $\begin{array}{l}\text { Increase in reporting } \\
\text { and serious and new } \\
\text { ADRs }\end{array}$ \\
\hline $\begin{array}{l}\text { Bäckström } \\
\text { et al. } \\
2006^{39}\end{array}$ & Financial & $\begin{array}{l}\text { An economic } \\
\text { inducement (lottery } \\
\text { tickets) }\end{array}$ & $\begin{array}{l}\text { Information } \\
\text { about the main } \\
\text { purpose of } \\
\text { spontaneous } \\
\text { reporting of } \\
\text { ADRs and } \\
\text { feedback. }\end{array}$ & $\begin{array}{l}\text { No specific } \\
\text { area }\end{array}$ & $\begin{array}{l}\text { All } \\
\text { physicians } \\
\text { and } \\
\text { general } \\
\text { practition } \\
\text { ers within } \\
\text { the two } \\
\text { counties } \\
\text { were } \\
\text { included }\end{array}$ & 50 reports & 39 reports & 50 reports & 62 reports & $\begin{array}{l}59 \% \text { increase in } \\
\text { the intervention } \\
\text { group }(p<0.10) \text {. } \\
\text { No significant } \\
\text { difference } \\
\text { between the } \\
\text { reporting rates of } \\
\text { the two groups }\end{array}$ & $\begin{array}{l}\text { No significant } \\
\text { increase in the } \\
\text { number of serious } \\
\text { reports in the } \\
\text { intervention group } \\
\text { compared to the pre- } \\
\text { intervention period, } \\
\text { or the control group. }\end{array}$ \\
\hline $\begin{array}{l}\text { Tabali et } \\
\text { al. } 2009^{37}\end{array}$ & $\begin{array}{l}\text { Educational and } \\
\text { financial }\end{array}$ & $\begin{array}{l}\text { consisting of a one- } \\
\text { on-one ADR } \\
\text { training session } \\
\text { and newsletters; } \\
\text { telephone } \\
\text { reminders; } \\
\text { financial incentive }\end{array}$ & $\begin{array}{l}\text { No control } \\
\text { group }\end{array}$ & $\begin{array}{l}\text { Complement } \\
\text { ary and } \\
\text { Alternative } \\
\text { Medicine. }\end{array}$ & $\begin{array}{l}362 \\
\text { physicians } \\
\text { were } \\
\text { initially } \\
\text { contacted. } \\
38 \\
\text { physicians } \\
\text { participat } \\
\text { ed }\end{array}$ & - & $\begin{array}{l}116 \text { reports in } \\
\text { total. Median } \\
\text { monthly } \\
\text { reporting rate } \\
\text { of } 4.00 \text { (IQR } \\
3.00-7.50 \text { ) }\end{array}$ & - & $\begin{array}{l}288 \text { reports in } \\
\text { total. Overall } \\
\text { median monthly } \\
\text { reporting rate of } \\
14.00 \text { (IQR } 9.50- \\
19.50 \text { ) }\end{array}$ & $\begin{array}{l}\text { A statistically } \\
\text { significant } \\
\text { increase of } 148 \% \\
\text { overall } \\
(p<0.001) \text {. } \\
\text { Statistically } \\
\text { significant } \\
\text { increase through } \\
\text { the first } 16 \\
\text { months after the } \\
\text { intervention } \\
(p<0.005) \text { but } \\
\text { not in the last } 4 \\
\text { months period }\end{array}$ & $\begin{array}{l}\text { The completeness of } \\
\text { reports increased } \\
\text { significantly } \\
\text { (p<0.001). The } \\
\text { quality of the reports } \\
\text { did not increase } \\
\text { significantly (before } \\
\text { intervention: kappa } \\
0.15 \text { (95\%CI } 0.08- \\
0.29 \text { ), after } \\
\text { intervention: kappa } \\
0.43 \text { (95\%CI } 0.23- \\
0.63 \text { ) }\end{array}$ \\
\hline $\begin{array}{l}\text { Pedrós et } \\
\text { al. } 2009^{36}\end{array}$ & $\begin{array}{l}\text { Educational and } \\
\text { financial }\end{array}$ & $\begin{array}{l}\text { Financial } \\
\text { incentives, } \\
\text { meetings with the } \\
\text { pharmacovigilance } \\
\text { department, } \\
\text { reminder cards }\end{array}$ & $\begin{array}{l}\text { No control } \\
\text { group }\end{array}$ & $\begin{array}{l}\text { No specific } \\
\text { area }\end{array}$ & $\begin{array}{l}\text { All } \\
\text { physicians } \\
\text { (not } \\
\text { stated } \\
\text { how many } \\
\text { exactly) } \\
\text { at the } \\
\text { hospital } \\
\text { were } \\
\text { included }\end{array}$ & - & $\begin{array}{l}\text { Mean monthly } \\
\text { of 3.47 reports } \\
(95 \% \text { CI 1.90- } \\
5.03)\end{array}$ & - & $\begin{array}{l}\text { Significant increase } \\
\text { of a mean of } 0.74 \\
\text { reports per month } \\
(95 \% \text { CI } 0.62- \\
0.86)\end{array}$ & - & $\begin{array}{l}\text { There were two folds } \\
\text { increase in the } \\
\text { number of: serious } \\
\text { ADRs reported } \\
\text { ( } p<0.001) \text {. No } \\
\text { significant increase in } \\
\text { the number of } \\
\text { unknown ADRs } \\
(p=0.376) \text {; and new } \\
\text { drug ADRs } \\
(p=0.559) \text {. }\end{array}$ \\
\hline
\end{tabular}




\begin{tabular}{|c|c|c|c|c|c|c|c|c|c|c|c|}
\hline $\begin{array}{l}\text { Fang et al. } \\
2017^{21}\end{array}$ & $\begin{array}{l}\text { Policy/regulatory, } \\
\text { financial and } \\
\text { educational } \\
\text { intervention }\end{array}$ & $\begin{array}{l}\text { New antibiotic } \\
\text { regulations, } \\
\text { financial incentives; } \\
\text { training courses; } \\
\text { improvement of the } \\
\text { computer system; } \\
\text { regular publishing } \\
\text { of ADR } \\
\text { information; alerts } \\
\text { on serious ADRs; } \\
\text { and regulation of } \\
\text { antibiotic use }\end{array}$ & N/A & $\begin{array}{l}\text { Antimicrobia } \\
\text { Is }\end{array}$ & $\begin{array}{l}\text { All } \\
\text { physicians } \\
\text {, clinical } \\
\text { pharmacis } \\
\text { ts, and } \\
\text { nurses at } \\
\text { Jinshan } \\
\text { hospital } \\
\text { were } \\
\text { included }\end{array}$ & $\begin{array}{l}557 \text { ADRs } \\
\text { in total in } \\
\text { the pre- } \\
\text { interventi } \\
\text { on period }\end{array}$ & - & $\begin{array}{l}832 \text { ADRs in } \\
\text { total in the } \\
\text { post- } \\
\text { intervention } \\
\text { period }\end{array}$ & - & $\begin{array}{l}\text { No significant } \\
\text { difference in the } \\
\text { reporting rates } \\
\text { between the pre } \\
\text { intervention } \\
\text { period } \\
(0.0128 \%) \text { and } \\
\text { post intervention } \\
\text { period } \\
(0.011426 \%) \\
(p=0.8023) . \\
\text { Significant } \\
\text { increase in total } \\
\text { reports between } \\
\text { the pre } \\
\text { intervention } \\
\text { period }(n=557) \\
\text { and post } \\
\text { intervention } \\
\text { period }(n=832) \\
(p=0.0086)\end{array}$ & $\begin{array}{l}\text { There were } \\
\text { improvements in } \\
\text { reporting compliance } \\
\text { in the post } \\
\text { intervention period. } \\
\text { Increase in reporting } \\
\text { of serious ADRs }\end{array}$ \\
\hline $\begin{array}{l}\text { Roy, Ma } \\
2018^{19}\end{array}$ & $\begin{array}{l}\text { Policy/regulatory } \\
\text { intervention }\end{array}$ & $\begin{array}{l}\text { Policy focused on } \\
\text { when, how and } \\
\text { who should report } \\
\text { ADRs }\end{array}$ & $\mathrm{N} / \mathrm{A}$ & None & $67 \%$ & - & $47 \%$ & - & $45 \%$ & $2 \%$ & - \\
\hline $\begin{array}{l}\text { Avong et } \\
\text { al. } 2018^{18}\end{array}$ & $\begin{array}{l}\text { Educational } \\
\text { intervention }\end{array}$ & $\begin{array}{l}\text { A structured } \\
\text { Pharmacovigilance } \\
\text { training and } \\
\text { workshop }\end{array}$ & N/A & $\begin{array}{l}\mathrm{HIV/Tb/Mala} \\
\mathrm{ria}\end{array}$ & $98.2 \%$ & $\begin{array}{l}\text { Not } \\
\text { reported }\end{array}$ & 1099 & 805 & 3000 & $273 \%$ & $\begin{array}{l}100 \% \text { correctness of } \\
\text { the report post } \\
\text { intervention }\end{array}$ \\
\hline $\begin{array}{l}\text { Aldeyab et } \\
\text { al. } 2016^{22}\end{array}$ & Educational & $\begin{array}{l}\text { Posters and leaflets } \\
\text { for patients to } \\
\text { promote yellow } \\
\text { card reporting } \\
\text { including display in } \\
\text { pharmacy; } \\
\text { Information sheets } \\
\text { for community } \\
\text { pharmacists and } \\
\text { received } \\
\text { remuneration }\end{array}$ & $\begin{array}{l}\text { No } \\
\text { promotional } \\
\text { campaign }\end{array}$ & $\begin{array}{l}\text { Herbal } \\
\text { medicines, } \\
\text { but also all } \\
\text { medicines }\end{array}$ & $\begin{array}{l}\text { Interventi } \\
\text { on group } \\
\mathrm{n}= \\
5,295,400 \\
\text { inhabitant } \\
\text { s; control } \\
\text { group } \mathrm{n}= \\
8,266,000 \\
\text { inhabitant } \\
\mathrm{s}\end{array}$ & $\begin{array}{l}\text { Northern } \\
\text { and } \\
\text { Yorkshire: } \\
\text { Patients: } \\
0.004 \\
\text { Communit } \\
\text { y } \\
\text { pharmacis } \\
\text { ts: } 0.001 \\
\text { GPs: } \\
0.009 \\
\text { ADR }\end{array}$ & $\begin{array}{l}\text { Northern and } \\
\text { Yorkshire: } \\
\text { Patients: } 0.004 \\
\text { Community } \\
\text { pharmacists: } \\
0.002 \\
\text { GPs: } 0.014\end{array}$ & $\begin{array}{l}\text { During the } \\
\text { promotional } \\
\text { period: } \\
\text { Scotland: } \\
\text { Patients: } \\
0.002 \\
\text { Community } \\
\text { pharmacists: } \\
0.002 \\
\text { GPs: } 0.007\end{array}$ & $\begin{array}{l}\text { Only GPs } \\
\text { significantly } \\
(p=0.001) \text { increase } \\
\text { d their ADR } \\
\text { reporting }\end{array}$ & - & $\begin{array}{l}\text { Observable } \\
\text { improvement in } \\
\text { reporting for the } \\
\text { quality indicators } \\
\text { reaction outcome, } \\
\text { patient age, patient } \\
\text { initials, patient weight } \\
\text { and height, and route } \\
\text { of administration. No } \\
\text { statistics were } \\
\text { provided }\end{array}$ \\
\hline $\begin{array}{l}\text { Ríos et al. } \\
2016^{23}\end{array}$ & Educational & $\begin{array}{l}\text { Educational session } \\
\text { including clinic } \\
\text { visits, reminders } \\
\text { and accessibility of } \\
\text { reporting system }\end{array}$ & $\begin{array}{l}\text { No control } \\
\text { group }\end{array}$ & $\begin{array}{l}\text { Paediatrics } \\
\text { in the } \\
\text { emergency } \\
\text { department. }\end{array}$ & $\begin{array}{l}\text { All } 62 \\
\text { physicians } \\
\text { based at } \\
\text { the } \\
\text { emergenc } \\
\text { y } \\
\text { departme }\end{array}$ & - & $\begin{array}{l}6.1 \% \text { of ADRs } \\
\text { were reported } \\
\text { (does not state } \\
\text { the actual } \\
\text { number) }\end{array}$ & - & $\begin{array}{l}41.2 \% \text { of ADRs } \\
\text { during the } \\
\text { intervention; } \\
41.7 \% 6 \text { months } \\
\text { post the } \\
\text { intervention }\end{array}$ & $35.6 \%(p<0.05)$ & Not measured \\
\hline $\begin{array}{l}\text { Srikanth } \\
\text { et al. } \\
2016^{24}\end{array}$ & Educational & $\begin{array}{l}\text { Participants given a } \\
\text { training manual } \\
\text { about ADR } \\
\text { reporting }\end{array}$ & $\begin{array}{l}\text { No control } \\
\text { group }\end{array}$ & $\begin{array}{l}\text { No specific } \\
\text { area. }\end{array}$ & $\begin{array}{l}26 \\
\text { pharmacis } \\
\text { ts }\end{array}$ & $\begin{array}{l}7.69 \% \\
(n=2)\end{array}$ & & $\begin{array}{l}57.69 \% \\
(n=15)\end{array}$ & & $650 \%$ & $\begin{array}{l}\text { Intervention } \\
\text { improved the } \\
\text { participants's } \\
\text { knowledge, attitude, } \\
\text { and practice towards } \\
\text { ADRs and ADR } \\
\text { reporting. }\end{array}$ \\
\hline
\end{tabular}




\begin{tabular}{|c|c|c|c|c|c|c|c|c|c|c|c|}
\hline $\begin{array}{l}\text { Lopez- } \\
\text { Gonzalez } \\
\text { et al. } \\
2015^{25}\end{array}$ & Educational & $\begin{array}{l}\text { An active and a } \\
\text { passive approach. } \\
\text { The active } \\
\text { approach consisting } \\
\text { of group sessions, } \\
\text { including a } \\
\text { presentation }\end{array}$ & $\begin{array}{l}\text { Normal } \\
\text { practice }\end{array}$ & $\begin{array}{l}\text { No specific } \\
\text { area. }\end{array}$ & - & $\begin{array}{l}31.3 / 1000 \\
\text { participan } \\
\text { ts }\end{array}$ & $\begin{array}{l}28.1 / \text { per } 1000 \\
\text { participants }\end{array}$ & $\begin{array}{l}31.1 / 1000 \\
\text { participants }\end{array}$ & $\begin{array}{l}39.6 / 1000 \\
\text { participants }\end{array}$ & $\begin{array}{l}65.4 \%(95 \% \mathrm{CI} \\
8.2-153.4) . \mathrm{RR} \\
1.65(95 \% \mathrm{CI} \\
1.08-2.53 \\
\mathrm{p}=0.021)\end{array}$ & $\begin{array}{l}\text { Non-significant } \\
\text { increases in reporting } \\
\text { of serious ADRs and } \\
\text { High causality ADRs } \\
\text { post intervention. } \\
\text { Significant increases } \\
\text { in reporting of } \\
\text { Unexpected ADRs }\end{array}$ \\
\hline $\begin{array}{l}\text { Biagi et al. } \\
2013^{26}\end{array}$ & Educational & $\begin{array}{l}\text { A monthly } \\
\text { newsletter on drug } \\
\text { safety was sent to } \\
\text { all participants via } \\
\text { e-mail for } 10 \\
\text { months }\end{array}$ & $\begin{array}{l}\text { Received no } \\
\text { newsletter; } \\
\text { therefore the } \\
\text { ADR reports } \\
\text { should be } \\
\text { uninfluenced } \\
\text { by the } \\
\text { intervention }\end{array}$ & $\begin{array}{l}\text { No specific } \\
\text { area. }\end{array}$ & $\begin{array}{l}\text { Response } \\
\text { rate: } \\
22.8 \% \\
(n=168)\end{array}$ & $\begin{array}{l}2.51 \\
\text { reports by } \\
\text { GPs per } \\
100,000 \\
\text { inhabitant } \\
\mathrm{s}\end{array}$ & $\begin{array}{l}\text { 0.5 reports by } \\
\text { GPs per } \\
100,000 \\
\text { inhabitants }\end{array}$ & $\begin{array}{l}\text { Intervention } \\
\text { period Control } \\
\text { group: } 1.59 \\
\text { reports by GPs } \\
\text { per } 100,000 \\
\text { inhabitants; } \\
12 \text { months } \\
\text { post } \\
\text { intervention: } \\
2.21 \text { per } \\
100,000 \\
\text { inhabitants }\end{array}$ & $\begin{array}{l}1.47 \text { reports by } \\
\text { GPs per } 100,000 \\
\text { inhabitants; } 12 \\
\text { months post } \\
\text { intervention } 0.97 \\
\text { per } 100,000 \\
\text { inhabitants }\end{array}$ & $\begin{array}{l}\text { Intervention } \\
\text { period: } \\
\text { intervention } \\
\text { group: rose by } \\
49.2 \% \text { vs pre } \\
\text { intervention } \\
\text { control group: } \\
\text { increased by } \\
8.8 \% \text { vs pre } \\
\text { intervention. } 12 \\
\text { months post } \\
\text { intervention } \\
\text { period saw } \\
\text { reports decrease } \\
\text { by } 6.4 \% \text { in the } \\
\text { intervention } \\
\text { group compared } \\
\text { to } 4.3 \% \text { fall in } \\
\text { the control group }\end{array}$ & $\begin{array}{l}\text { 'Good quality' reports } \\
\text { in the pre } \\
\text { intervention, } \\
\text { intervention, and post } \\
\text { intervention periods }\end{array}$ \\
\hline $\begin{array}{l}\text { Herdeiro } \\
\text { et al. } \\
2012^{27}\end{array}$ & Educational & $\begin{array}{l}\text { One intervention } \\
\text { group received } \\
\text { telephone } \\
\text { interviews, and the } \\
\text { other received } \\
\text { educational } \\
\text { workshops }\end{array}$ & Usual practice & $\begin{array}{l}\text { No specific } \\
\text { area. }\end{array}$ & $\begin{array}{l}200 \\
\text { physicians } \\
\text { received } \\
\text { one of the } \\
\text { interventi } \\
\text { ons. } \\
\text { Participati } \\
\text { on rate } \\
\text { for the } \\
\text { workshop } \\
\text { was } \\
26.9 \% \\
(n=118) \\
\text { and } 7.9 \% \\
(n=82) \\
\text { for the } \\
\text { telephone } \\
\text { interviews }\end{array}$ & $\begin{array}{l}\text { ADR } \\
\text { reporting } \\
\text { rate per } \\
1000 \\
\text { physician } \\
\text { years: } \\
\\
\text { Control: } \\
10.3\end{array}$ & $\begin{array}{l}\text { Baseline ADR } \\
\text { reporting rate } \\
\text { per } 1000 \\
\text { physician } \\
\text { years: } \\
\text { Workshop: } \\
10.41 \\
\text { Telephone } \\
\text { interview: } 19.9\end{array}$ & $\begin{array}{l}\text { ADR reporting } \\
\text { rate per } 1000 \\
\text { physician } \\
\text { years post- } \\
\text { intervention: } \\
\text { Overall: } \\
\text { Control: } 12.0\end{array}$ & $\begin{array}{l}\text { ADR reporting rate } \\
\text { per } 1000 \text { physician } \\
\text { years: } \\
\text { Post-intervention: } \\
\text { Overall: } \\
\text { Workshop: } 52.7 \\
\text { Telephone } \\
\text { interview: } 22.7\end{array}$ & $\begin{array}{l}\text { Overall } 20 \\
\text { months post } \\
\text { intervention, } \\
\text { ADR reporting } \\
\text { Workshop } \\
\text { RR: } 3.97 ; 95 \% \mathrm{CI} \\
3.86-4.08 ; \mathrm{p}< \\
0.001) \\
\text { Telephone RR: } \\
1.02 ; 95 \% \mathrm{CI} \\
1.00,1.04\end{array}$ & $\begin{array}{l}\text { Effect of intervention } \\
\text { on reports of serious } \\
\text { ADRs: } \\
\text { Workshop: RR: } 6.84 ; \\
95 \% \text { CI } 6.69-6.98 ; \\
\text { p<0.001 } \\
\text { Telephone interview: } \\
\text { RR: } 0.93 ; 95 \% \text { CI } \\
0.91-0.94 ; p<0.001 \\
\text { Effect of intervention } \\
\text { on reports of high- } \\
\text { causality ADRs: } \\
\text { Workshop: RR: } 3.58 \text {; } \\
95 \% \text { CI } 3.51-3.66 ; \\
\text { p<0.001 } \\
\text { Telephone interview: } \\
\text { RR: } 0.75 ; 95 \% \text { CI } \\
0.73-0.76 ; p<0.001\end{array}$ \\
\hline $\begin{array}{l}\text { Gerritsen } \\
\text { et al. } \\
2011^{29}\end{array}$ & Educational & $\begin{array}{l}\text { One set of } \\
\text { graduates } \\
\text { undertook lecture- } \\
\text { based } \\
\text { pharmacovigilance } \\
\text { training, while the } \\
\text { other undertook } \\
\text { practice-based } \\
\text { training }\end{array}$ & $\begin{array}{l}\text { No control } \\
\text { group }\end{array}$ & $\begin{array}{l}\text { No specific } \\
\text { area. }\end{array}$ & $\begin{array}{l}\text { All } 259 \\
\text { participan } \\
\text { ts } \\
\text { enrolled } \\
\text { were } \\
\text { included } \\
\text { and } \\
\text { participat } \\
\text { ed }\end{array}$ & $\begin{array}{l}\text { No } \\
\text { baseline } \\
\text { or pre- } \\
\text { interventi } \\
\text { on rate } \\
\text { given }\end{array}$ & - & $\begin{array}{l}\text { Lecture- } \\
\text { based: } 2.1 \\
\text { ADR reports } \\
\text { per } 1000 \\
\text { months of } \\
\text { follow up. } \\
\text { Practice- } \\
\text { based: } 6.8 \\
\text { reports per } \\
1000 \text { months } \\
\text { of follow up }\end{array}$ & - & $\begin{array}{l}\text { Practice-based } \\
\text { trainees made } \\
\text { statistically } \\
\text { significantly } \\
\text { more ADR } \\
\text { reports (hazard } \\
\text { ratio 2.9; } 95 \% \\
\text { CI 1.4-6.1) }\end{array}$ & $\begin{array}{l}\text { Practice-based } \\
\text { trainees submitted } \\
\text { significantly higher } \\
\text { quality reports (odds } \\
\text { ratio 5.0; } 95 \% \text { CI } \\
1.1-23.6 \text { ). Practice- } \\
\text { based trainees } \\
\text { submitted } \\
\text { significantly more } \\
\text { unlabelled ADR } \\
\text { reports (odds ratio } \\
3.3 ; 95 \% \text { CI } 1.1- \\
10.1 \text { ). }\end{array}$ \\
\hline
\end{tabular}




\begin{tabular}{|c|c|c|c|c|c|c|c|c|c|c|c|}
\hline $\begin{array}{l}\text { Johansson } \\
\text { et al. } \\
2011^{30}\end{array}$ & Educational & $\begin{array}{l}\text { An information } \\
\text { sheet (letter) }\end{array}$ & Usual practice & $\begin{array}{l}\text { No specific } \\
\text { area }\end{array}$ & $\begin{array}{l}\text { All staff at } \\
\text { the } \\
\text { primary } \\
\text { healthcar } \\
\text { e units } \\
\text { were } \\
\text { included. }\end{array}$ & $\begin{array}{l}\text { Mean } \\
\text { (SD) } \\
\text { number of } \\
\text { reports } \\
\text { per } \\
\text { primary } \\
\text { healthcare } \\
\text { unit }=0.7 \\
(1.1)\end{array}$ & $\begin{array}{l}\text { Mean (SD) } \\
\text { number of } \\
\text { reports per } \\
\text { primary } \\
\text { healthcare } \\
\text { unit }=0.8(1.4)\end{array}$ & $\begin{array}{l}\text { Mean (SD) } \\
\text { number of } \\
\text { reports per } \\
\text { primary } \\
\text { healthcare } \\
\text { unit }(S D)=0.7 \\
(1.2)\end{array}$ & $\begin{array}{l}\text { Mean (SD) number } \\
\text { of reports per } \\
\text { primary healthcare } \\
\text { unit }=1.0(2.5)\end{array}$ & $p=0.34$ & $\begin{array}{l}\text { The number of high } \\
\text { quality reports was } \\
\text { higher in intervention } \\
\text { units than in control } \\
\text { units (mean (SD) } \\
\text { number of reports per } \\
\text { unit }=0.5(0.9) \text { vs. } \\
0.2(0.6), p=0.048 \text { ) }\end{array}$ \\
\hline $\begin{array}{l}\text { Ribeiro- } \\
\text { Vaz et al. } \\
2011^{31}\end{array}$ & Educational & $\begin{array}{l}\text { Either a workshop } \\
\text { or a telephone } \\
\text { intervention }\end{array}$ & $\begin{array}{l}\text { Received } \\
\text { neither } \\
\text { intervention. } \\
\text { Continued } \\
\text { normal } \\
\text { practice and so } \\
\text { the number } \\
\text { and types of } \\
\text { ADR reports } \\
\text { provided from } \\
\text { the controls } \\
\text { should not be } \\
\text { altered by the } \\
\text { intervention. }\end{array}$ & $\begin{array}{l}\text { No specific } \\
\text { area }\end{array}$ & $\begin{array}{l}\text { Worksho: } \\
52 \% \\
\text { participati } \\
\text { on rate } \\
(n=52 \%) . \\
\text { Telephone } \\
\text { interventi } \\
\text { on: } 36 \% \\
(n=94)\end{array}$ & $\begin{array}{l}\text { All } \\
\text { numbers } \\
\text { are } \\
\text { reports } \\
\text { per one } \\
\text { thousand } \\
\text { pharmacis } \\
\text { ts per } \\
\text { month. } \\
\text { Control: } \\
1.76\end{array}$ & $\begin{array}{l}\text { Workshop: } \\
7.65 \\
\text { Telephone } \\
\text { intervention: } \\
1.69\end{array}$ & $\begin{array}{l}4 \text { month } \\
\text { control: } 3.85 \\
20 \text { month- } \\
\text { control: } 1.59\end{array}$ & $\begin{array}{l}\text { Workshop: } \\
4 \text { months: } 48.5 \\
20 \text { month: } 1.6 \\
\text { Telephone } \\
\text { intervention: } \\
4 \text { months: } 12.5 \\
20 \text { month: } 4.9\end{array}$ & $\begin{array}{l}\text { Increase ADR } \\
\text { reports in both } \\
\text { intervention } \\
\text { groups compared } \\
\text { to control (RR } \\
3.22,95 \% \text { CI } \\
1.33-7.80)\end{array}$ & $\begin{array}{l}\text { No significant change } \\
\text { in the number of } \\
\text { number of reports } \\
\text { with high probability } \\
\text { compared to controls. } \\
\text { Increase in severe } \\
\text { ADR reports in both } \\
\text { intervention groups } \\
\text { compared to control } \\
\text { (RR 3.87, 95\% CI } \\
1.29-11.61) . \\
\text { Increase in } \\
\text { unexpected ADR } \\
\text { reports in both } \\
\text { intervention groups } \\
\text { compared to control } \\
\text { (RR 5.02, 95\% CI } \\
1.33-18.93) \text {. }\end{array}$ \\
\hline $\begin{array}{l}\text { Gony et } \\
\text { al. } 2010^{32}\end{array}$ & Educational & $\begin{array}{l}\text { Meetings with } \\
\text { healthcare } \\
\text { professionals }\end{array}$ & $\begin{array}{l}\text { Received visits } \\
\text { from the } \\
\text { Clinical } \\
\text { Research } \\
\text { Assistant }\end{array}$ & $\begin{array}{l}\text { No specific } \\
\text { area. }\end{array}$ & $\begin{array}{l}\text { All } \\
\text { healthcar } \\
\text { e } \\
\text { profession } \\
\text { als at the } \\
\text { included } \\
\text { administr } \\
\text { ation } \\
\text { regions } \\
\text { were } \\
\text { included. }\end{array}$ & $\begin{array}{l}\text { Reporting } \\
\text { rate=num } \\
\text { ber of } \\
\text { reports } / n \\
\text { umber of } \\
\text { beds } \\
\text { Control } \\
\text { region: } \\
\text { reporting } \\
\text { rate } 0.3 \%\end{array}$ & $\begin{array}{l}\text { First } \\
\text { intervention } \\
\text { region: } \\
\text { reporting rate } \\
11 \% \\
\text { Second } \\
\text { intervention } \\
\text { region: } \\
\text { reporting rate } \\
3 \%\end{array}$ & $\begin{array}{l}\text { Control } \\
\text { region: } \\
\text { reporting rate } \\
2006=0 \% ; \\
2007=1 \% ; \\
2008=1 \%\end{array}$ & $\begin{array}{l}\text { number of } \\
\text { reports/number of } \\
\text { beds } \\
\text { First intervention } \\
\text { region: reporting } \\
\text { rate } 2006=23 \% ; \\
2007=18 \% ; \\
2008=40 \% \\
\text { Second } \\
\text { intervention } \\
\text { region: reporting } \\
\text { rate } 2006=13 \% ; \\
2007=13 \% ; \\
2008=25 \%\end{array}$ & $\begin{array}{l}\text { The increase was } \\
\text { statistically } \\
\text { significant in the } \\
\text { first and second } \\
\text { intervention } \\
\text { regions (both } \\
\text { p<0.05). There } \\
\text { was no } \\
\text { significant } \\
\text { change in the } \\
\text { control region } \\
\text { (no statistics) }\end{array}$ & - \\
\hline $\begin{array}{l}\text { Johansson } \\
\text { et al. } \\
2009^{34}\end{array}$ & Educational & Emails reminders & $\begin{array}{l}\text { Received no } \\
\text { emails }\end{array}$ & $\begin{array}{l}\text { No specific } \\
\text { area }\end{array}$ & $\begin{array}{l}\text { All staff at } \\
\text { the } \\
\text { included } \\
\text { primary } \\
\text { healthcar } \\
\text { e units } \\
\text { were } \\
\text { included }\end{array}$ & $\begin{array}{l}89 \text { ADR } \\
\text { reports } \\
\text { altogether } \\
\text { from both } \\
\text { the } \\
\text { interventi } \\
\text { on and } \\
\text { control } \\
\text { primary } \\
\text { healthcare } \\
\text { units }\end{array}$ & $\begin{array}{l}89 \text { ADR reports } \\
\text { altogether } \\
\text { from both the } \\
\text { intervention } \\
\text { and control } \\
\text { primary } \\
\text { healthcare } \\
\text { units }\end{array}$ & $\begin{array}{l}55 \text { reports in } \\
\text { total }\end{array}$ & 56 reports in total & $\begin{array}{l}\text { Overall a } 25 \% \\
\text { increase in the } \\
\text { intervention } \\
\text { group, which was } \\
\text { statistically } \\
\text { significant } \\
\text { ( } p=0.037) \text {. } \\
\text { No significant } \\
\text { difference } \\
\text { between the } \\
\text { control and } \\
\text { intervention } \\
\text { group }\end{array}$ & $\begin{array}{l}\text { The proportion of } \\
\text { high-quality reports } \\
\text { before and after the } \\
\text { intervention did not } \\
\text { significantly change in } \\
\text { the intervention } \\
\text { group ( } 36 \% \text { vs } 48 \% \text {, } \\
\text { p } 0.0 .11 \text { ) or the } \\
\text { control group (40\%, } \\
\text { vs } 36 \%, p=0.55 \text { ). } \\
\text { The proportion of } \\
\text { high-quality reports } \\
\text { did not differ between } \\
\text { the groups ( } p=0.53 \text { ). }\end{array}$ \\
\hline
\end{tabular}




\begin{tabular}{|c|c|c|c|c|c|c|c|c|c|c|c|}
\hline $\begin{array}{l}\text { Herdeiro } \\
\text { et al. } \\
2008^{38}\end{array}$ & Educational & $\begin{array}{l}\text { Educational } \\
\text { session, leaflets } \\
\text { and reminders }\end{array}$ & Usual practice & $\begin{array}{l}\text { No specific } \\
\text { area. }\end{array}$ & $\begin{array}{l}80.7 \% \\
(\mathrm{n}=276) \\
\text { of } \\
\text { pharmacis } \\
\text { ts in the } \\
\text { interventi } \\
\text { on group } \\
\text { attended } \\
\text { the } \\
\text { interventi } \\
\text { on }\end{array}$ & $\begin{array}{l}29.2 \\
\text { reports } \\
\text { per } 1000 \\
\text { pharmacis } \\
\text { t years }\end{array}$ & $\begin{array}{l}32.3 \text { reports } \\
\text { per } 1000 \\
\text { pharmacist } \\
\text { years. }\end{array}$ & $\begin{array}{l}\text { Overall: } 47.6 \\
4 \text { month: } 24.7 \\
16 \text { month: } \\
31.1 \text { per } 1000 \\
\text { pharmacist } \\
\text { years. }\end{array}$ & $\begin{array}{l}\text { Overall: } 326.3 \\
4 \text { month: } 570.0 \\
16 \text { month: } 114.6\end{array}$ & $\begin{array}{l}\text { Statistically } \\
\text { significant } \\
\text { increase in } \\
\text { reporting rate } \\
\text { (increase }=275.6 \\
\text { reports per } 1000 \\
\text { pharmacist } \\
\text { years; } 95 \% \text { CI } \\
162.15-389.12 ; \\
\text { RR } 5.87,95 \% \\
C I 1.98-17.39, \\
p=0.001) \\
\text { compared to the } \\
\text { pre intervention } \\
\text { period. } \\
\text { Significantly } \\
\text { more reports } \\
\text { than in the } \\
\text { control group } \\
\text { also }(5.49 \text { fold } \\
\text { increase, } 95 \% \mathrm{CI} \\
2.37-12.75) .\end{array}$ & $\begin{array}{l}\text { Significant increase } \\
\text { for all quality } \\
\text { indicators. For serious } \\
\text { ADRs }(10 \text {-fold } \\
\text { increase, RR = 9.79; } \\
p=0.002), \\
\text { unexpected ADRs (4- } \\
\text { fold increase, RR = } \\
4.41 ; p=0.04 \text {, high- } \\
\text { causality ADRs (9-fold } \\
\text { increase, RR = 8.67; } \\
p=0.002), \text { and new } \\
\text { drug-related ADRRs ( } 9 \text { - } \\
\text { fold increase, RR = } \\
9.33 ; p<0.001) .\end{array}$ \\
\hline $\begin{array}{l}\text { Figueiras } \\
\text { et al. } \\
2006^{40}\end{array}$ & Educational & $\begin{array}{l}\text { A continuing } \\
\text { medical education } \\
\text { multifaceted } \\
\text { intervention; this } \\
\text { included an out- } \\
\text { reach visit, } \\
\text { reminder card, and } \\
\text { report form }\end{array}$ & $\begin{array}{l}\text { The control } \\
\text { clusters did } \\
\text { not receive the } \\
\text { educational } \\
\text { intervention. }\end{array}$ & $\begin{array}{l}\text { No specific } \\
\text { area }\end{array}$ & $\begin{array}{l}655 \text { of } \\
1388 \\
\text { physicians } \\
(47.2 \%) \\
\text { in the } \\
\text { interventi } \\
\text { on group } \\
\text { attended } \\
\text { the } \\
\text { interventi } \\
\text { on }\end{array}$ & $\begin{array}{l}\text { Control } \\
\text { group: } \\
11.3 \\
\text { reports } \\
\text { per } 1000 \\
\text { physician } \\
\text { years }\end{array}$ & $\begin{array}{l}\text { Intervention: } \\
7.6 \text { reports per } \\
1000 \text { physician } \\
\text { years }\end{array}$ & $\begin{array}{l}\text { All numbers } \\
\text { are reports } \\
\text { per } 1000 \\
\text { physician } \\
\text { years. } \\
\text { Overall: } 14.5 \\
4 \text { month: } 13.1 \\
16 \text { month: } \\
15.1\end{array}$ & $\begin{array}{l}\text { Intervention: } \\
\text { Overall: } 100.2 \\
4 \text { month: } 205.2 \\
16 \text { month: } 55.3\end{array}$ & $\begin{array}{l}\text { The adjusted } \\
\text { increase in ADR } \\
\text { reporting rates } \\
\text { attributable } \\
\text { to intervention } \\
\text { was } 90.19 \text { for } \\
\text { total ADRs ( } 95 \% \\
\text { confidence } \\
\text { interval [CI], } \\
54.51- \\
125.87 \text {; relative } \\
\text { risk [RR], 10.23; } \\
95 \% \text { CI, } 3.81- \\
27.51)\end{array}$ & 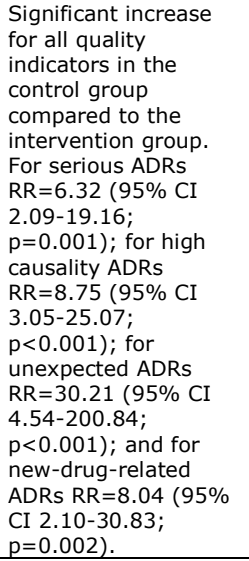 \\
\hline $\begin{array}{l}\text { Bracchi et } \\
\text { al. } 2005^{41}\end{array}$ & Educational & $\begin{array}{l}\text { A distance-learning } \\
\text { programme in } \\
\text { pharmacovigilance }\end{array}$ & $\begin{array}{l}\text { Received no } \\
\text { training. } \\
\text { Continued } \\
\text { normal } \\
\text { practice and so } \\
\text { the number } \\
\text { and types of } \\
\text { ADR reports } \\
\text { provided from } \\
\text { the controls } \\
\text { should not be } \\
\text { altered by the } \\
\text { intervention. }\end{array}$ & $\begin{array}{l}\text { No specific } \\
\text { area }\end{array}$ & $\begin{array}{l}13 \% \\
(n=261) \\
\text { of } \\
\text { pharmacis } \\
\text { ts } \\
\text { completed } \\
\text { and } 27 \% \\
(n=477) \\
\text { of general } \\
\text { practition } \\
\text { ers } \\
\text { completed } \\
\text { the } \\
\text { module }\end{array}$ & - & $\begin{array}{l}\text { Pharmacists: } \\
\text { 297 reports. } \\
\text { GPs: } 1439 \\
\text { reports }\end{array}$ & - & $\begin{array}{l}\text { Pharmacists: } 440 \\
\text { reports. } \\
\text { GPs: } 2781 \text { reports }\end{array}$ & $\begin{array}{l}\text { Pharmacist ADR } \\
\text { reporting } \\
\text { increase } 92 \% \\
\text { ( } p<0.001) \\
\text { compared to the } \\
\text { pre intervention } \\
\text { period and GP } \\
\text { reporting } 131 \% . \\
\text { ( } p<0.001 \text { ) } \\
\text { pharmacists }\end{array}$ & $\begin{array}{l}\text { Increase in } \\
\text { 'appropriate' reports } \\
\text { by GPs and } \\
\text { pharmacists by } \\
15.6 \%(p<0.001) \text {. } \\
11.5 \% \text { reduction in } \\
\text { the 'appropriate' } \\
\text { report } 12 \text { months } \\
\text { post study }\end{array}$ \\
\hline
\end{tabular}




\begin{tabular}{|c|c|c|c|c|c|c|c|c|c|c|c|}
\hline $\begin{array}{l}\text { Lata et al. } \\
2004^{42}\end{array}$ & Educational & $\begin{array}{l}\text { The nurse case } \\
\text { managers screened } \\
\text { patients at } \\
\text { admission and } \\
\text { follow them } \\
\text { through their } \\
\text { inpatient stay. } \\
\text { They were trained } \\
\text { on how to report } \\
\text { ADRs }\end{array}$ & $\begin{array}{l}\text { No control } \\
\text { group }\end{array}$ & $\begin{array}{l}\text { No specific } \\
\text { area }\end{array}$ & $\begin{array}{l}\text { All staff at } \\
\text { the } \\
\text { hospital } \\
\text { who could } \\
\text { report } \\
\text { ADRs } \\
\text { were } \\
\text { included. }\end{array}$ & $\begin{array}{l}\text { 1998: } 2.1 \\
\text { ADR } \\
\text { reports } \\
\text { per } 100 \\
\text { admission } \\
\mathrm{s}\end{array}$ & - & $\begin{array}{l}\text { 2000: } 4.5 \mathrm{ADR} \\
\text { reports per } \\
100 \\
\text { admissions } \\
2001: 5.3 \\
\text { reports per } \\
100 \\
\text { admissions }\end{array}$ & - & None stated. & $\begin{array}{l}\text { The number of } \\
\text { serious ADRs } \\
\text { reported increased } \\
\text { and that the nurse } \\
\text { case managers were } \\
\text { the largest reporter of } \\
\text { these }\end{array}$ \\
\hline $\begin{array}{l}\text { Castel et } \\
\text { al. } 2003^{43}\end{array}$ & Educational & $\begin{array}{l}\text { Quarterly ADR } \\
\text { bulletins and } \\
\text { reporting forms } \\
\text { attached to } \\
\text { prescription pads }\end{array}$ & $\begin{array}{l}\text { No control } \\
\text { group }\end{array}$ & $\begin{array}{l}\text { No specific } \\
\text { area. }\end{array}$ & $\begin{array}{l}\text { All } \\
\text { practising } \\
\text { physicians } \\
\text { within the } \\
\text { catchmen } \\
\text { t area of } \\
\text { the } \\
\text { Catalan } \\
\text { Centre of } \\
\text { Pharmaco } \\
\text { vigilance } \\
\text { were } \\
\text { included }\end{array}$ & Not stated & - & $\begin{array}{l}\text { Overall mean } \\
\text { increase in } \\
\text { ADR reports } \\
\text { after a bulletin } \\
\text { was } 11.7 \\
\text { reports. Mean } \\
\text { increase in } \\
\text { month } \\
\text { following } \\
\text { bulletin: } 12.3 \\
\text { reports (95\% } \\
\text { CI } 7.2-17.4 \text {; } \\
\text { Following the } \\
\text { attachment of } \\
\text { reports to } \\
\text { prescription } \\
\text { pads: monthly } \\
\text { reporting rate } \\
\text { was } 19.8 \\
\text { (95\% CI 12.5- } \\
27.0)\end{array}$ & - & None stated. & - \\
\hline $\begin{array}{l}\text { Bäckström } \\
\text { et al. } \\
2002^{44}\end{array}$ & Educational & $\begin{array}{l}\text { Educational } \\
\text { interventions } \\
\text { including lectures }\end{array}$ & $\begin{array}{l}\text { Received no } \\
\text { training. } \\
\text { Continued } \\
\text { normal } \\
\text { practice and so } \\
\text { the number } \\
\text { and types of } \\
\text { ADR reports } \\
\text { provided from } \\
\text { the controls } \\
\text { should not be } \\
\text { altered by the } \\
\text { intervention }\end{array}$ & $\begin{array}{l}\text { No specific } \\
\text { area, other } \\
\text { than } \\
\text { occurring in } \\
\text { geriatric } \\
\text { wards }\end{array}$ & $\begin{array}{l}\text { All } 117 \\
\text { nurses } \\
\text { working } \\
\text { at the two } \\
\text { geriatric } \\
\text { medicine } \\
\text { units were } \\
\text { invited to } \\
\text { attend. } \\
\text { Actual } \\
\text { participati } \\
\text { on rate } \\
\text { was not } \\
\text { given }\end{array}$ & Not stated & $\begin{array}{l}2 \text { reports from } \\
\text { the two } \\
\text { departments in } \\
\text { the year prior } \\
\text { to the study }\end{array}$ & $\begin{array}{l}15 \text { reports } \\
\text { (0.4 reports } \\
\text { per } 1000 \\
\text { admissions) }\end{array}$ & $\begin{array}{l}18 \text { reports ( } 11 \\
\text { reports per } 1000 \\
\text { admissions) }\end{array}$ & None stated. & - \\
\hline $\begin{array}{l}\text { Ortega et } \\
\text { al. } 2008^{35}\end{array}$ & $\begin{array}{l}\text { A new electronic } \\
\text { system }\end{array}$ & $\begin{array}{l}\text { It facilitated ADR } \\
\text { reporting through } \\
\text { easy use, } \\
\text { automatic input of } \\
\text { certain information, } \\
\text { and increased } \\
\text { accessibility }\end{array}$ & $\begin{array}{l}\text { No control } \\
\text { group }\end{array}$ & $\begin{array}{l}\text { No specific } \\
\text { area. }\end{array}$ & $\begin{array}{l}\text { All } \\
\text { doctors, } \\
\text { nurses } \\
\text { and } \\
\text { pharmacis } \\
\text { ts at the } \\
\text { hospital } \\
\text { were } \\
\text { included } \\
\text { in the } \\
\text { study }\end{array}$ & - & Null reports & - & $\begin{array}{l}\text { Phase I: } 0.91 \\
\text { yellow card reports } \\
\text { per month. } \\
\text { Phase II: } 1.62 \\
\text { yellow card reports } \\
\text { per month }\end{array}$ & $\begin{array}{l}\text { No percentages } \\
\text { or statistics } \\
\text { stated }\end{array}$ & Not measured \\
\hline
\end{tabular}




\begin{tabular}{|c|c|c|c|c|c|c|c|c|c|c|c|}
\hline $\begin{array}{l}\text { Yen et al. } \\
2010^{33}\end{array}$ & $\begin{array}{l}\text { Electronic system, } \\
\text { financial }\end{array}$ & $\begin{array}{l}\text { Introduction of an } \\
\text { Electronic ADE } \\
\text { management } \\
\text { system, financial } \\
\text { reward }\end{array}$ & $\begin{array}{l}\text { No control } \\
\text { group }\end{array}$ & $\begin{array}{l}\text { No specific } \\
\text { area }\end{array}$ & $\begin{array}{l}\text { All } \\
\text { medical } \\
\text { staff }\end{array}$ & - & $\begin{array}{l}108 \text { ADR } \\
\text { reports were } \\
\text { received }\end{array}$ & -- & $\begin{array}{l}394 \text { ADR reports } \\
\text { were received }\end{array}$ & $\begin{array}{l}3.6 \text {-fold increase } \\
(p<0.0001) \text {. No } \\
\text { statistics given } \\
\text { for the total } \\
\text { number of } \\
\text { reports }\end{array}$ & $\begin{array}{l}\text { The severity } \\
\text { difference between } \\
\text { before the } \\
\text { introduction of the } \\
\text { computerised ADR } \\
\text { system and after its } \\
\text { introduction were } \\
\text { significantly different } \\
\text { ( }<<0.001)\end{array}$ \\
\hline $\begin{array}{l}\text { Ribeiro- } \\
\text { Vaz et al. } \\
2012^{28}\end{array}$ & $\begin{array}{l}\text { Electronic } \\
\text { reminders to the } \\
\text { electronic patient } \\
\text { records or to the } \\
\text { computer desktops }\end{array}$ & $\begin{array}{l}\text { The hyperlink took } \\
\text { participants to an } \\
\text { online ADR } \\
\text { reporting form }\end{array}$ & $\begin{array}{l}\text { No hyperlink } \\
\text { to an ADR } \\
\text { reporting form } \\
\text { was added }\end{array}$ & $\begin{array}{l}\text { No specific } \\
\text { area. }\end{array}$ & $\begin{array}{l}\text { All staff } \\
\text { from } 11 \\
\text { hospitals } \\
\text { were } \\
\text { included }\end{array}$ & - & $\begin{array}{l}\text { Median of } 2 \\
\text { ADR reports } \\
\text { per month }\end{array}$ & - & $\begin{array}{l}\text { Median of } 5 \mathrm{ADR} \\
\text { reports per month. }\end{array}$ & $\begin{array}{l}\text { Statistically } \\
\text { significant } \\
\text { increase in } \\
\text { reporting rate } \\
(p=0.009)\end{array}$ & - \\
\hline
\end{tabular}

CI: Confidence Intervals, GP: general practitioner N/A: not applicable 
Figure 1: Risk of bias assessment 


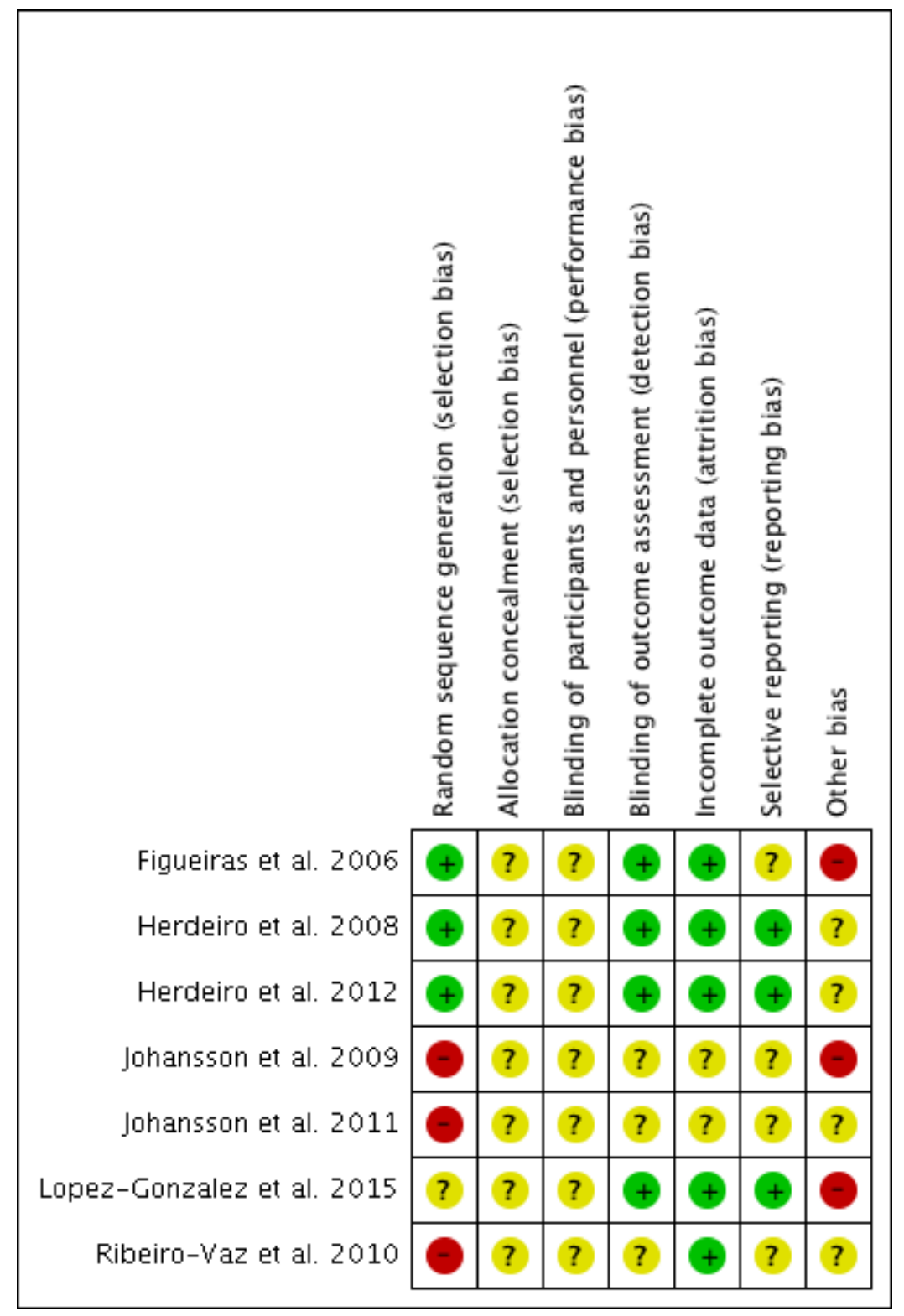



Figure 2: Forest plots depicting effectiveness of interventions to improve ADR reporting across three outcomes (Overall ADRs, Serious ADRs and Unexpected ADRs)

\section{Overall ADRs}

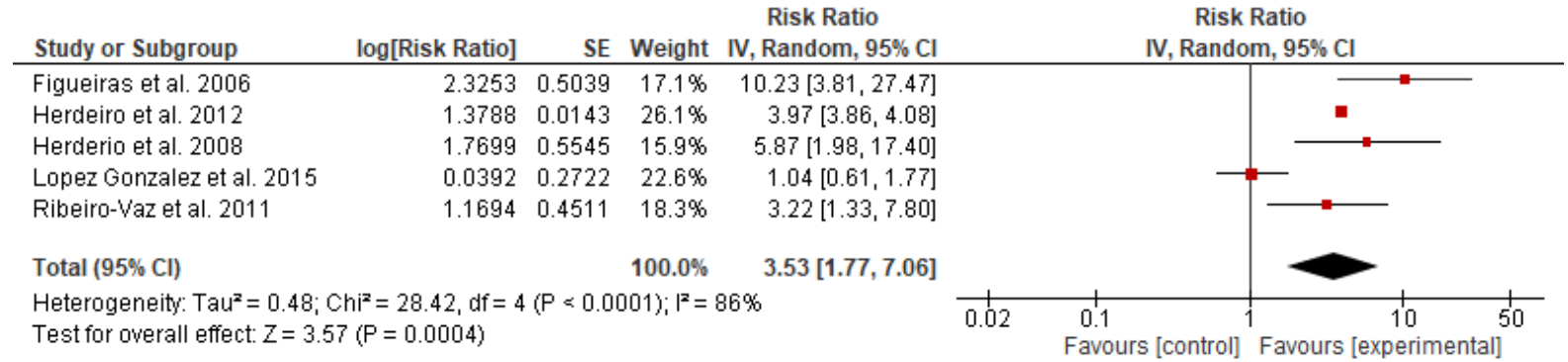




\section{Serious ADRs}

\begin{tabular}{|c|c|c|c|c|c|c|c|}
\hline Study or Subgroup & log[Risk Ratio] & SE & Weight & $\begin{array}{c}\text { Risk Ratio } \\
\text { IV, Random, } 95 \% \mathrm{Cl}\end{array}$ & \multicolumn{3}{|c|}{$\begin{array}{c}\text { Risk Ratio } \\
\text { IV, Random, } 95 \% \mathrm{Cl}\end{array}$} \\
\hline Figueiras et al. 2006 & 1.8437 & 0.5646 & $18.5 \%$ & $6.32[2.09,19.11]$ & & & $\longrightarrow$ \\
\hline Herdeiro et al. 2012 & 1.9228 & 0.0113 & $25.5 \%$ & $6.84[6.69,6.99]$ & & & - \\
\hline Herderio et al. 2008 & 2.2814 & 0.7525 & $15.2 \%$ & $9.79[2.24,42.79]$ & & & \\
\hline Lopez Gonzalez et al. 2015 & 0 & 0.3537 & $22.2 \%$ & $1.00[0.50,2.00]$ & & - & - \\
\hline Ribeiro-Vaz et al. 2011 & 1.3533 & 0.5605 & $18.6 \%$ & $3.87[1.29,11.61]$ & & & \\
\hline Total $(95 \% \mathrm{Cl})$ & & & $100.0 \%$ & $4.18[1.69,10.33]$ & & & \\
\hline $\begin{array}{l}\text { Heterogeneity: } \text { Tau }^{2}=0.83 ; 0 \\
\text { Test for overall effect: } Z=3.1\end{array}$ & $\begin{array}{l}\mathrm{hi}=30.80, \mathrm{df}=4 \\
(\mathrm{P}=0.002)\end{array}$ & $4(P<0.00)$ & $0001) ; 1^{2}=$ & & 0.01 & $\begin{array}{c}0.1 \\
\text { Favours [Control] }\end{array}$ & $\begin{array}{c}10 \\
\text { Favours [Experimental] }\end{array}$ \\
\hline
\end{tabular}

\section{Unexpected ADRs}

\begin{tabular}{|c|c|c|c|c|c|c|c|c|}
\hline \multirow{2}{*}{$\begin{array}{l}\text { Study or Subgroup } \\
\text { Figueiras et al. } 2006\end{array}$} & log[Risk Ratio] & SE & Weight & $\begin{array}{c}\text { Risk Ratio } \\
\text { IV, Random, } 95 \% \mathrm{CI}\end{array}$ & \multicolumn{4}{|c|}{$\begin{array}{c}\text { Risk Ratio } \\
\text { IV, Random, } 95 \% \mathrm{Cl}\end{array}$} \\
\hline & 3.4082 & 0.967 & $10.6 \%$ & $30.21[4.54,201.04]$ & & & & \\
\hline Herdeiro et al. 2012 & 1.9228 & 0.0113 & $31.2 \%$ & $6.84[6.69,6.99]$ & & & & - \\
\hline Herderio et al. 2008 & 1.4839 & 0.7038 & $15.4 \%$ & $4.41[1.11,17.52]$ & & & & \\
\hline Lopez Gonzalez et al. 2015 & 0.7227 & 0.28 & $26.8 \%$ & $2.06[1.19,3.57]$ & & & $\longrightarrow-$ & \\
\hline Ribeiro-Vaz et al. 2011 & 1.6134 & 0.6777 & $16.0 \%$ & $5.02[1.33,18.95]$ & & & & \\
\hline Total $(95 \% \mathrm{Cl})$ & & & $100.0 \%$ & $5.16[2.42,11.03]$ & & & & \\
\hline $\begin{array}{l}\text { Heterogeneity: } \operatorname{Tau}^{2}=0.48 \text {; } \\
\text { Test for overall effect: } Z=4 \text {. }\end{array}$ & $\begin{array}{l}\mathrm{hi}^{2}=21.30, \mathrm{df}=4 \\
\mathrm{t}(\mathrm{P}<0.0001)\end{array}$ & $(P=0.00$ & 003); $\left.\right|^{2}=$ & & 0.01 & $\begin{array}{c}0.1 \\
\text { Favours [controll] }\end{array}$ & Favours ! & $\begin{array}{c}10 \\
\text { [experimental] }\end{array}$ \\
\hline
\end{tabular}




\section{Figure legends}

Figure 1: Risk of bias assessment

Legends not applicable

Figure 2: Forest plots Forest plots depicting effectiveness of interventions to improve ADR reporting across three outcomes (Overall ADRs, Serious ADRs and Unexpected ADRs)

Legends not applicable 


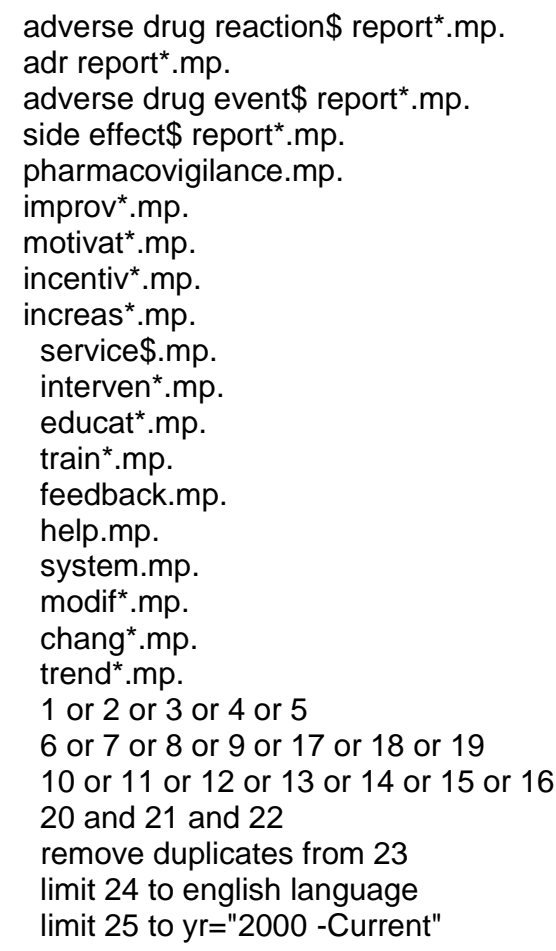

limit 24 to english language

limit 25 to $y r=" 2000$-Current" 
Supplement 2: PRISMA flowchart 

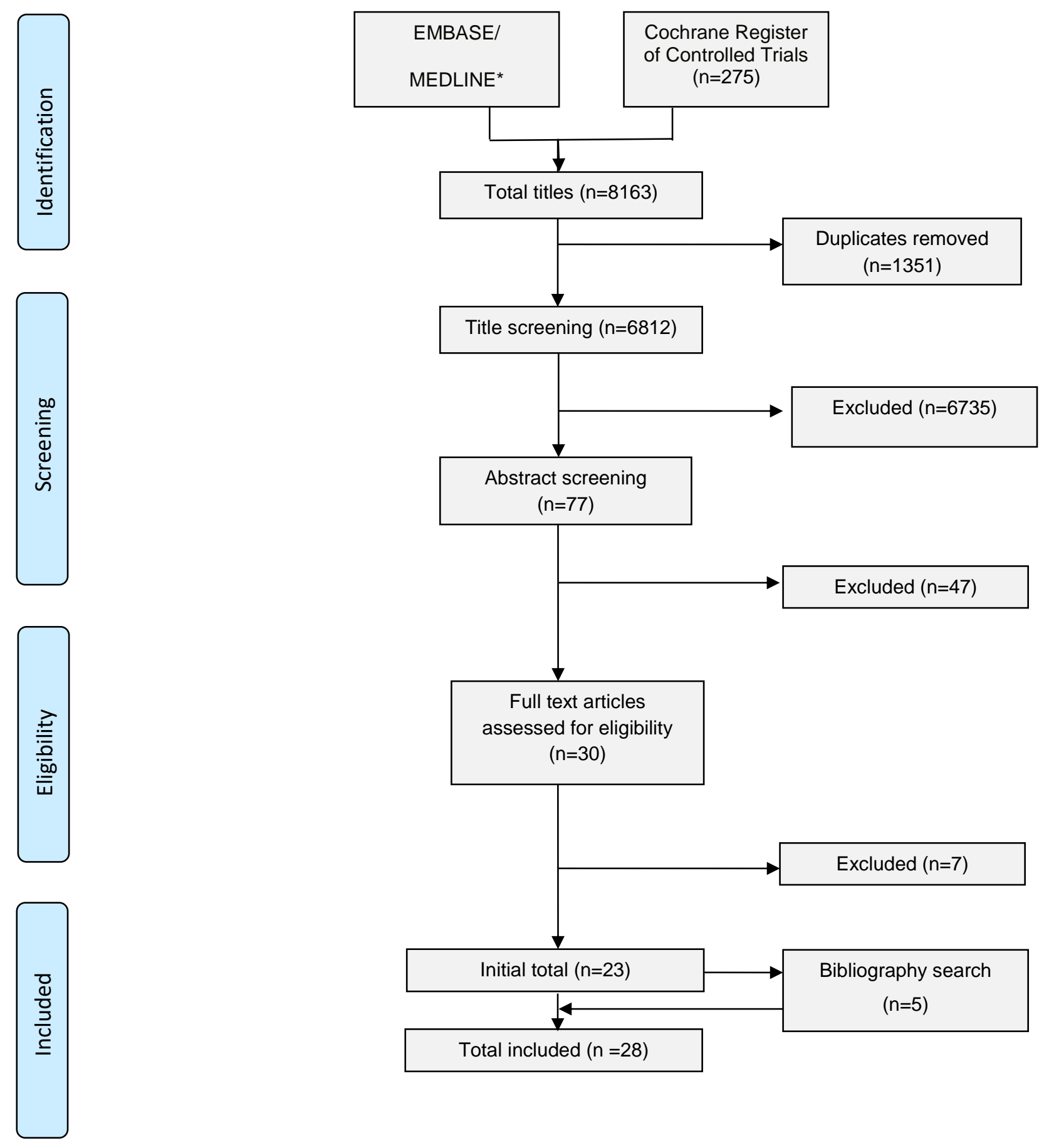
PRISMA: Preferred reporting items for systematic reviews and meta-analysis; *databases searched concurrently Supplement 3: Risk of bias assessment (review level)

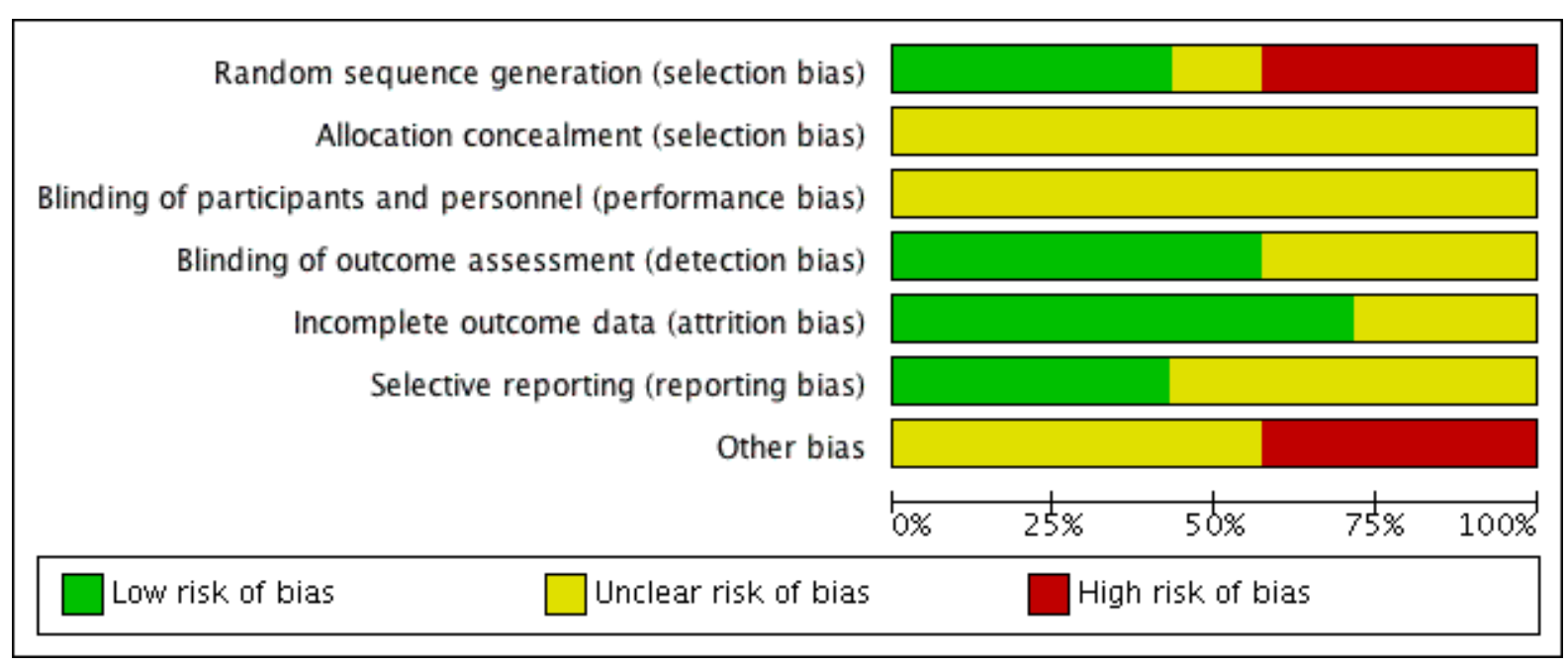


Supplementary material 4

Quality assessment of non-randomised studies

\begin{tabular}{|c|c|c|c|c|c|c|c|c|c|c|c|}
\hline & $\begin{array}{l}\text { Did the study } \\
\text { address a } \\
\text { clearly focused } \\
\text { issue? }\end{array}$ & $\begin{array}{l}\text { Was the } \\
\text { cohort } \\
\text { recruited in } \\
\text { an acceptable } \\
\text { way? }\end{array}$ & $\begin{array}{l}\text { Was the exposure } \\
\text { accurately measured } \\
\text { to minimise bias? }\end{array}$ & $\begin{array}{l}\text { Was the } \\
\text { outcome } \\
\text { accurately } \\
\text { measured to } \\
\text { minimise } \\
\text { bias? }\end{array}$ & $\begin{array}{l}\text { Have the } \\
\text { authors } \\
\text { identified all } \\
\text { important } \\
\text { confounding } \\
\text { factors? }\end{array}$ & $\begin{array}{l}\text { Have they } \\
\text { taken an } \\
\text { account of the } \\
\text { confounding } \\
\text { factors in the } \\
\text { design and/or } \\
\text { analysis? }\end{array}$ & $\begin{array}{l}\text { Was the } \\
\text { follow up of } \\
\text { subjects } \\
\text { complete } \\
\text { enough? }\end{array}$ & $\begin{array}{l}\text { Was the } \\
\text { follow up } \\
\text { of subjects } \\
\text { long } \\
\text { enough? }\end{array}$ & $\begin{array}{l}\text { Are the } \\
\text { results } \\
\text { precise? }\end{array}$ & $\begin{array}{l}\text { Do you } \\
\text { believe the } \\
\text { results? }\end{array}$ & $\begin{array}{l}\text { Do the } \\
\text { results of } \\
\text { this study fit } \\
\text { with other } \\
\text { available } \\
\text { evidence? }\end{array}$ \\
\hline $\begin{array}{c}\text { Aldeyab et al. } \\
2016\end{array}$ & Yes & Yes & Yes & Yes & Can't tell & Can't tell & No & No & Can't tell & Can't tell & Yes \\
\hline $\begin{array}{c}\text { Avong et al. } \\
2018\end{array}$ & Yes & Yes & Yes & Yes & Can't tell & Can't tell & Can't tell & Can't tell & Yes & Yes & Yes \\
\hline $\begin{array}{l}\text { Roy and Ma } \\
2018\end{array}$ & Yes & Yes & Yes & Yes & Can't tell & Can't tell & Yes & Yes & Yes & Yes & Yes \\
\hline $\begin{array}{c}\text { Chang et al. } \\
2017\end{array}$ & Ye & Yes & Yes & Yes & Can't tell & Can't tell & Yes & Yes & Yes & Yes & Yes \\
\hline $\begin{array}{c}\text { Fang et al. } \\
2017\end{array}$ & Yes & Yes & No & Yes & Can't tell & Can't tell & Yes & Yes & Can't tell & Yes & Yes \\
\hline $\begin{array}{l}\text { Rios et al. } \\
2016\end{array}$ & Yes & Yes & Yes & Yes & Can't tell & Can't tell & Yes & Yes & Yes & Yes & Yes \\
\hline $\begin{array}{c}\text { Baker et al. } \\
2015\end{array}$ & Yes & Yes & Can't tell & Yes & Can't tell & Can't tell & Yes & Yes & Yes & Yes & Yes \\
\hline $\begin{array}{l}\text { Srikanth et al. } \\
2015\end{array}$ & Yes & Can't tell & Can't tell & No & Can't tell & Can't tell & Yes & No & Can't tell & Yes & Yes \\
\hline $\begin{array}{c}\text { Biagi et al. } \\
2013\end{array}$ & Yes & Yes & Yes & Yes & Can't tell & Can't tell & No & No & No & Can't tell & Yes \\
\hline $\begin{array}{l}\text { Gerritsen et } \\
\text { al. } 2011\end{array}$ & Yes & Yes & Yes & Yes & Can't tell & Can't tell & yes & yes & Yes & Yes & Yes \\
\hline $\begin{array}{l}\text { Ribeiro-Vaz et } \\
\text { al. } 2011\end{array}$ & Yes & Yes & Yes & Yes & can't tell & Can't tell & Yes & yes & Yes & Yes & yes \\
\hline $\begin{array}{c}\text { Gony et al. } \\
2010\end{array}$ & Yes & Yes & Can't tell & can't tell & Can't tell & Can't tell & Yes & Yes & Yes & Yes & Yes \\
\hline $\begin{array}{l}\text { Yen et al. } \\
2010\end{array}$ & Can't tell & Yes & Yes & Yes & Can't tell & Can't tell & Yes & Yes & Yes & Yes & Yes \\
\hline $\begin{array}{c}\text { Pedros et al. } \\
2009\end{array}$ & yes & Yes & Yes & Yes & Can't tell & Can't tell & yes & Yes & Yes & Yes & Yes \\
\hline $\begin{array}{c}\text { Tabali et al. } \\
2009 \\
\end{array}$ & Yes & Yes & Yes & Yes & Can't tell & Can't tell & Yes & Yes & Yes & Yes & Yes \\
\hline $\begin{array}{c}\text { Ortega et al. } \\
2008\end{array}$ & Can't tell & Yes & can't tell & Yes & Can't tell & Can't tell & Yes & Yes & Yes & Can't tell & Can't tell \\
\hline
\end{tabular}




\begin{tabular}{|c|c|c|c|c|c|c|c|c|c|c|c|}
\hline $\begin{array}{l}\text { Backstrom et } \\
\text { al.2006 }\end{array}$ & Yes & Yes & Yes & Yes & Can't tell & Can't tell & Yes & Yes & Can't tell & Yes & Yes \\
\hline $\begin{array}{c}\text { Bracchi et al. } \\
2005 \\
\end{array}$ & Yes & No & Yes & Yes & Can't tell & Can't tell & No & No & Yes & Yes & Yes \\
\hline $\begin{array}{c}\text { Lata et al. } \\
2004\end{array}$ & Can't tell & Yes & Can't tell & Yes & Can't tell & Can't tell & Yes & Yes & Yes & Ye & Yes \\
\hline $\begin{array}{c}\text { Castel et al } \\
2003 \\
\end{array}$ & Yes & Yes & Yes & Yes & Can't tell & Can't tell & Yes & Yes & Yes & Yes & Yes \\
\hline $\begin{array}{l}\text { Backstrom et } \\
\text { al.2001 }\end{array}$ & Yes & Yes & Yes & Yes & Can't tell & Can't tell & Yes & No & Can't tell & Can't tell & Yes \\
\hline
\end{tabular}




\section{Supplementary material 5}

\section{PRISMA Checklist ${ }^{1}$}

\begin{tabular}{|c|c|c|c|}
\hline Section/topic & \# & Checklist item & $\begin{array}{l}\text { Reported } \\
\text { Y/N/NA and } \\
\text { page number } \\
\text { or section in } \\
\text { the } \\
\text { manuscript } \\
\end{array}$ \\
\hline \multicolumn{4}{|l|}{ TITLE } \\
\hline Title & 1 & Identify the report as a systematic review, meta-analysis, or both. & Y, title \\
\hline Structured summary & 2 & $\begin{array}{l}\text { Provide a structured summary including, as applicable: background; objectives; data sources; study eligibility criteria, participants, and } \\
\text { interventions; study appraisal and synthesis methods; results; limitations; conclusions and implications of key findings; systematic review } \\
\text { registration number. }\end{array}$ & $\begin{array}{l}\text { Y, structured } \\
\text { abstract }\end{array}$ \\
\hline \multicolumn{4}{|l|}{ INTRODUCTION } \\
\hline Rationale & 3 & Describe the rationale for the review in the context of what is already known. & $\begin{array}{l}\text { Y, } \\
\text { introduction }\end{array}$ \\
\hline Objectives & 4 & $\begin{array}{l}\text { Provide an explicit statement of questions being addressed with reference to participants, interventions, comparisons, outcomes, and study } \\
\text { design (PICOS). }\end{array}$ & Y, aim \\
\hline Protocol and registration & 5 & $\begin{array}{l}\text { Indicate if a review protocol exists, if and where it can be accessed (e.g., Web address), and, if available, provide registration information } \\
\text { including registration number. }\end{array}$ & $Y$, page $x$ \\
\hline Eligibility criteria & 6 & $\begin{array}{l}\text { Specify study characteristics (e.g., PICOS, length of follow-up) and report characteristics (e.g., years considered, language, publication status) } \\
\text { used as criteria for eligibility, giving rationale. }\end{array}$ & $\mathrm{Y}$, methods \\
\hline Information sources & 7 & $\begin{array}{l}\text { Describe all information sources (e.g., databases with dates of coverage, contact with study authors to identify additional studies) in the search } \\
\text { and date last searched. }\end{array}$ & $\begin{array}{l}\text {, methods/ } \\
\text { data sources }\end{array}$ \\
\hline Search & 8 & Present full electronic search strategy for at least one database, including any limits used, such that it could be repeated. & Y, Appendix 2 \\
\hline Study selection & 9 & $\begin{array}{l}\text { State the process for selecting studies (i.e., screening, eligibility, included in systematic review, and, if applicable, included in the meta- } \\
\text { analysis). }\end{array}$ & Y, methods \\
\hline Data collection process & 10 & $\begin{array}{l}\text { Describe method of data extraction from reports (e.g., piloted forms, independently, in duplicate) and any processes for obtaining and } \\
\text { confirming data from investigators. }\end{array}$ & $\begin{array}{l}\mathrm{Y}, \\
\text { methods/data } \\
\text { extraction }\end{array}$ \\
\hline
\end{tabular}




\begin{tabular}{|c|c|c|c|}
\hline Data items & 11 & List and define all variables for which data were sought (e.g., PICOS, funding sources) and any assumptions and simplifications made. & $\begin{array}{l}\mathrm{Y}, \\
\text { methods/data } \\
\text { extraction }\end{array}$ \\
\hline Risk of bias in individual studies & 12 & $\begin{array}{l}\text { Describe methods used for assessing risk of bias of individual studies (including specification of whether this was done at the study or outcome } \\
\text { level), and how this information is to be used in any data synthesis. }\end{array}$ & $\begin{array}{l}\text { Y, } \\
\text { methods/risk } \\
\text { of bias and } \\
\text { quality } \\
\text { assessment }\end{array}$ \\
\hline Summary measures & 13 & State the principal summary measures (e.g., risk ratio, difference in means). & $\begin{array}{l}\mathrm{Y}, \\
\text { methods/data } \\
\text { synthesis }\end{array}$ \\
\hline Synthesis of results & 14 & $\begin{array}{l}\left.\text { Describe the methods of handling data and combining results of studies, if done, including measures of consistency (e.g., } \mathrm{I}^{2}\right) \text { for each meta- } \\
\text { analysis. }\end{array}$ & $\begin{array}{l}\mathrm{Y}, \\
\text { methods/data } \\
\text { synthesis }\end{array}$ \\
\hline
\end{tabular}

\begin{tabular}{|c|c|c|c|}
\hline Section/topic & \# & Checklist item & $\begin{array}{l}\text { Reported on } \\
\text { page \# }\end{array}$ \\
\hline Risk of bias across studies & 15 & Specify any assessment of risk of bias that may affect the cumulative evidence (e.g., publication bias, selective reporting within studies). & $\begin{array}{l}\text { Y, } \\
\text { results/discussion }\end{array}$ \\
\hline Additional analyses & 16 & Describe methods of additional analyses (e.g., sensitivity or subgroup analyses, meta-regression), if done, indicating which were pre-specified. & NA \\
\hline \multicolumn{4}{|l|}{ RESULTS } \\
\hline Study selection & 17 & $\begin{array}{l}\text { Give numbers of studies screened, assessed for eligibility, and included in the review, with reasons for exclusions at each stage, ideally with a } \\
\text { flow diagram. }\end{array}$ & Y, Fig 1 \\
\hline Study characteristics & 18 & For each study, present characteristics for which data were extracted (e.g., study size, PICOS, follow-up period) and provide the citations. & Y Tables 1 and 2 \\
\hline Risk of bias within studies & 19 & Present data on risk of bias of each study and, if available, any outcome level assessment (see item 12). & $\begin{array}{l}\text { Y, Figures } 2 \text { and } \\
3\end{array}$ \\
\hline Results of individual studies & 20 & $\begin{array}{l}\text { For all outcomes considered (benefits or harms), present, for each study: (a) simple summary data for each intervention group (b) effect estimates } \\
\text { and confidence intervals, ideally with a forest plot. }\end{array}$ & $\begin{array}{l}\text { Yes, figures } 4,5 \\
\text { and } 6\end{array}$ \\
\hline Synthesis of results & 21 & Present results of each meta-analysis done, including confidence intervals and measures of consistency. & $\begin{array}{l}\mathrm{NA}, \\
\text { methodological }\end{array}$ \\
\hline
\end{tabular}




\begin{tabular}{|c|c|c|c|}
\hline & & & $\begin{array}{l}\text { systematic } \\
\text { review }\end{array}$ \\
\hline Risk of bias across studies & 22 & Present results of any assessment of risk of bias across studies (see Item 15). & $\begin{array}{l}\text { Y, results/risk of } \\
\text { bias, quality } \\
\text { assessment }\end{array}$ \\
\hline Additional analysis & 23 & Give results of additional analyses, if done (e.g., sensitivity or subgroup analyses, meta-regression [see Item 16]). & NA \\
\hline \multicolumn{4}{|l|}{ DISCUSSION } \\
\hline Summary of evidence & 24 & $\begin{array}{l}\text { Summarize the main findings including the strength of evidence for each main outcome; consider their relevance to key groups (e.g., healthcare } \\
\text { providers, users, and policy makers). }\end{array}$ & Y, results \\
\hline Limitations & 25 & $\begin{array}{l}\text { Discuss limitations at study and outcome level (e.g., risk of bias), and at review-level (e.g., incomplete retrieval of identified research, reporting } \\
\text { bias). }\end{array}$ & Y, discussion \\
\hline Conclusions & 26 & Provide a general interpretation of the results in the context of other evidence, and implications for future research. & Y discussion \\
\hline \multicolumn{4}{|l|}{ FUNDING } \\
\hline Funding & 27 & Describe sources of funding for the systematic review and other support (e.g., supply of data); role of funders for the systematic review. & $\begin{array}{l}\text { Y, Online } \\
\text { submission } \\
\text { system }\end{array}$ \\
\hline
\end{tabular}

${ }^{1}$ Moher D, Liberati A, Tetzlaff J, Altman DG, The PRISMA Group (2009). Preferred Reporting Items for Systematic Reviews and Meta-Analyses: The PRISMA Statement. PLoS Med 6(7): e1000097.doi:10.1371/journal.pmed1000097

NA: Not applicable 